\title{
An assessment of the performance of the Monitor for AeRosols and GAses in ambient air (MARGA): a semi-continuous method for soluble compounds
}

\author{
I. C. Rumsey ${ }^{1}$, K. A. Cowen ${ }^{2}$, J. T. Walker ${ }^{1}$, T. J. Kelly ${ }^{2}$, E. A. Hanft ${ }^{2}$, K. Mishoe ${ }^{3}$, C. Rogers ${ }^{3}$, R. Proost ${ }^{4}$, \\ G. M. Beachley ${ }^{5}$, G. Lear ${ }^{5}$, T. Frelink ${ }^{4}$, and R. P. Otjes ${ }^{6}$ \\ ${ }^{1}$ Office of Research and Development, US Environmental Protection Agency, Research Triangle Park, NC 27711, USA \\ ${ }^{2}$ Battelle, Columbus, OH, 43201, USA \\ ${ }^{3}$ AMEC, Jacksonville, FL, 32669, USA \\ ${ }^{4}$ Metrohm Applikon B.V., Schiedam, the Netherlands \\ ${ }^{5}$ Clean Air Markets Division, US Environmental Protection Agency, Washington, DC 20460, USA \\ ${ }^{6}$ Energy Research Centre of the Netherlands (ECN), Petten, the Netherlands
}

Correspondence to: I. Rumsey (rumsey.ian@epa.gov)

Received: 7 August 2013 - Published in Atmos. Chem. Phys. Discuss.: 26 September 2013

Revised: 5 December 2013 - Accepted: 8 April 2014 - Published: 6 June 2014

\begin{abstract}
Ambient air monitoring as part of the US Environmental Protection Agency's (US EPA's) Clean Air Status and Trends Network (CASTNet) currently uses filter packs to measure weekly integrated concentrations. The US EPA is interested in supplementing CASTNet with semicontinuous monitoring systems at select sites to characterize atmospheric chemistry and deposition of nitrogen and sulfur compounds at higher time resolution than the filter pack. The Monitor for AeRosols and GAses in ambient air (MARGA) measures water-soluble gases and aerosols at an hourly temporal resolution. The performance of the MARGA was assessed under the US EPA Environmental Technology Verification (ETV) program. The assessment was conducted in Research Triangle Park, North Carolina, from 8 September to 8 October 2010 and focused on gaseous $\mathrm{SO}_{2}, \mathrm{HNO}_{3}$, and $\mathrm{NH}_{3}$ and aerosol $\mathrm{SO}_{4}^{2-}, \mathrm{NO}_{3}^{-}$, and $\mathrm{NH}_{4}^{+}$. Precision of the MARGA was evaluated by calculating the median absolute relative percent difference (MARPD) between paired hourly results from duplicate MARGA units (MUs), with a performance goal of $\leq 25 \%$. The accuracy of the MARGA was evaluated by calculating the MARPD for each MU relative to the average of the duplicate denuder/filter pack concentrations, with a performance goal of $\leq 40 \%$. Accuracy was also evaluated by using linear regression, where MU concentrations were plotted against the average of the duplicate
\end{abstract}

denuder/filter pack concentrations. From this, a linear least squares line of best fit was applied. The goal was for the slope of the line of best fit to be between 0.8 and 1.2. The MARGA performed well in comparison to the denuder/filter pack for $\mathrm{SO}_{2}, \mathrm{SO}_{4}^{2-}$, and $\mathrm{NH}_{4}^{+}$, with all three compounds passing the accuracy and precision goals by a significant margin. The performance of the MARGA in measuring $\mathrm{NO}_{3}^{-}$could not be evaluated due to the different sampling efficiency of coarse $\mathrm{NO}_{3}^{-}$by the MUs and the filter pack. Estimates of "fine" $\mathrm{NO}_{3}^{-}$were calculated for the MUs and the filter pack. Using this and results from a previous study, it is concluded that if the MUs and the filter pack were sampling the same particle size, the MUs would have good agreement in terms of precision and accuracy. The MARGA performed moderately well in measuring $\mathrm{HNO}_{3}$ and $\mathrm{NH}_{3}$, though neither met the linear regression slope goals. However, recommendations for improving the measurement of $\mathrm{HNO}_{3}$ and $\mathrm{NH}_{3}$ are discussed. It is concluded that $\mathrm{SO}_{4}^{2-}, \mathrm{SO}_{2}, \mathrm{NO}_{3}^{-}, \mathrm{HNO}_{3}, \mathrm{NH}_{4}^{+}$, and $\mathrm{NH}_{3}$ concentrations can be measured with acceptable accuracy and precision when the MARGA is operated in conjunction with the recommendations outlined in the manuscript. 


\section{Introduction}

The inorganic aerosol system comprising ammonium sulfate $\left[\left(\mathrm{NH}_{4}\right)_{2} \mathrm{SO}_{4}\right]$, ammonium bisulfate $\left(\mathrm{NH}_{4} \mathrm{HSO}_{4}\right)$, and ammonium nitrate $\left(\mathrm{NH}_{4} \mathrm{NO}_{3}\right)$, along with its gas phase precursors, sulfur dioxide $\left(\mathrm{SO}_{2}\right)$, ammonia $\left(\mathrm{NH}_{3}\right)$, and nitric acid $\left(\mathrm{HNO}_{3}\right)$, is of wide-ranging interest to the atmospheric and ecological research communities. This suite of compounds plays a role in particle and cloud formation, influences the optical properties of the atmosphere, and contributes a large fraction of the total atmospheric mass of $\mathrm{PM}_{2.5}$ (Adams et al., 1999). Additionally, this system is an important contributor to wet and dry atmospheric deposition of acidity and nutrients, thereby playing an important role in the acidification and eutrophication of terrestrial and aquatic ecosystems (Galloway et al., 2003; Galloway, 1995).

In 1991, the Clean Air Status and Trends Network (CASTNet) began monitoring to quantify temporal and spatial trends in atmospheric concentrations and dry deposition of nitrogen $(\mathrm{N})$ and sulfur (S) compounds. The network currently consists of more than 80 sites within the contiguous US, Canada, and Alaska, which are located in areas where urban influences are minimal. Air concentrations of $\mathrm{SO}_{2}$, $\mathrm{HNO}_{3}, \mathrm{NH}_{4}^{+}, \mathrm{NO}_{3}^{-}$, and $\mathrm{SO}_{4}^{2-}$ are measured at a weekly integrated timescale using a 3-stage filter pack (Sickles et al., 1999). The US Environmental Protection Agency (US EPA) is interested in supplementing CASTNet with semicontinuous monitoring systems at select sites to characterize atmospheric chemistry and deposition of $\mathrm{N}$ and $\mathrm{S}$ compounds at higher time resolution than is provided by the filter pack.

The Monitor for AeRosols and GAses in ambient air (MARGA; Metrohm Applikon B.V., the Netherlands) is an online ion chromatography based system that measures water-soluble gases and aerosols at an hourly temporal resolution. It is one member of a class of similar instruments that separate gases and aerosols into a liquid sample stream for online analysis, including the particle into liquid sampler (PILS, Weber et al., 2001), the ambient ion monitor (AIM; URG Corporation, USA; Nie et al., 2010), and the gasparticle ion chromatography system (GPIC; Dionex Corporation, USA; Godri et al., 2009). The MARGA (ten Brink et al., 2007), and earlier versions of the system (Wolff et al., 2010; Thomas et al., 2009; Trebs et al., 2004), employs a steam jet aerosol collector (SJAC; Slanina et al., 2001; Khlystov et al., 1995) for sampling of soluble aerosols and a wet rotating denuder (WRD; Wyers et al., 1993; Keuken et al., 1988) for the collection of water-soluble gases. The MARGA has previously been used for rural and urban air quality monitoring in Europe (Schaap et al., 2011; Makkonen et al., 2012) and Asia (Li et al., 2010). With respect to validation of the commercial MARGA instrument, Makkonen et al. (2012) present a linear regression of collocated MARGA and filter pack aerosol measurements. In addition, the Makkonen et al. (2012) study also presents a linear regression of collocated MARGA and TEI (Thermo Environmental Instruments) 43iTL SO 2 mea- surements. However, a comprehensive field-based evaluation of the accuracy and precision of the MARGA, for both gas and aerosol compounds, has not yet been published. While the MARGA technology meets the objectives of the EPA's CASTNet program with respect to the suite of compounds measured and temporal resolution, the performance of the instrument must be fully evaluated and documented prior to use within the network.

The objective of the present study was to evaluate rigorously the performance characteristics of duplicate MARGA $1 \mathrm{~S}$ instruments with respect to agreement between each other and to a reference system consisting of duplicate denuders and filter packs. This evaluation was conducted under the US EPA's Environmental Technology Verification (ETV) program, which verifies the performance of innovative technologies that have the potential to improve the protection of human health and the environment. This paper describes the MARGA and reference denuder/filter pack sampling systems, the methods for quantifying the precision and accuracy of the MARGA, the results of the comparison, and recommendations for controlling the accuracy of the MARGA for routine monitoring applications. A second objective of this paper is to investigate potential reasons for the agreement or disagreement between the MARGA and reference measurement system observed during the ETV test (US EPA, 2011), which is outside the scope of the ETV program. This includes an analysis of potential relationships between instrument performance and meteorology, an expanded assessment and application of data quality control measures, and, in some instances, alternative data reduction procedures. To provide a clear linkage between this paper and the ETV report (US EPA, 2011), a summary of the ETV results and an explanation of the differences in the reduction and analysis of the data between the two documents are included in the Supplement.

\section{Methods and materials}

\subsection{Sampling site and scheme}

The ETV was conducted at the ambient air innovation research site (AIRS) located on the EPA campus in Research Triangle Park, North Carolina $\left(35.89^{\circ} \mathrm{N}, 78.87^{\circ} \mathrm{W}\right)$. Maps of the location and surrounding area of the sampling site are provided in the Supplement. The sampling site is an open area characterized as urban and is influenced by mobile emissions. Duplicate MARGA units (MUs) were housed in a temperature-controlled trailer, which was over $200 \mathrm{~m}$ away from the closest building. The MU inlets were positioned just above the roof of the trailer $(\approx 3 \mathrm{~m}$ high). Duplicate denuder/filter packs were positioned on the roof of the trailer at the same height as the MU inlets. The distance between individual MARGA and denuder/filter pack inlets ranged from 0.7 to $2.9 \mathrm{~m}$ with an average distance of $1.9 \mathrm{~m}$. In addition, 
a continuous Model 43S pulsed fluorescence analyzer (PFA) (TEI, Mountain View, CA, USA) was used to measure $\mathrm{SO}_{2}$. The $\mathrm{SO}_{2}$ PFA was located in a different trailer, $\approx 30 \mathrm{~m}$ from the trailer where the MUs and denuder/filter pack systems were located. Information on $\mathrm{SO}_{2} \mathrm{PFA}$ measurements and comparison to the MUs is provided in the Supplement. The ETV test was conducted over a period of 30 days of continuous operation from 8 September 2010 to 8 October 2010.

\subsection{Sampling systems}

\subsubsection{MARGA}

\section{Description of MARGA system}

The MARGA is an online analyzer that semi-continuously measures water-soluble gases and aerosols at an hourly temporal resolution using ion chromatography. For the ETV test, a custom inertial separator inlet made of white acrylic with an aerodynamic particle size cutoff of $\approx 26 \mu \mathrm{m}$ was used with the MARGA. After passing through the inlet, the air sample flows through $\approx 4 \mathrm{~m}$ of polyethylene tubing $(1.25 \mathrm{~cm}$ outer diameter) to the sampling box. The sampling box contains a wet rotating denuder (WRD), which consists of two concentric glass cylinders. The glass walls of the WRD are coated with absorption solution, which causes the gases to diffuse into the aqueous film (Keuken et al., 1988; Wyers et al., 1993). The absorption solution consists of $18.2 \mathrm{M} \Omega \mathrm{cm}$ double deionized water (DDI) water with $10 \mathrm{ppm}$ of $\mathrm{H}_{2} \mathrm{O}_{2}$ added as a biocide. Particles pass through the WRD and enter the steam jet aerosol collector (SJAC) (Khlystov et al., 1995; Slanina et al., 2001). The SJAC injects steam into the sample flow, which creates a supersaturated environment. This results in the growth of particles by deliquescence, after which they are collected by inertial separation. The same absorption solution is also used for the SJAC. Air is drawn through the inlet tubing, the WRD, and the SJAC at $\approx 16.7 \mathrm{~L} \mathrm{~min}^{-1}$ using a vacuum pump (KNF Model PM24214-838, KNF Neuberger, Inc., Trenton, NJ, USA) and a mass flow controller (Model DMFM: D-6340DR, M+W Instruments, Leonhardsbuch, Germany). Each hour, the liquid sample streams from the WRD and SJAC are drawn into syringes with a volume of $25 \mathrm{ml}$. The syringe collection system is in a tandem configuration, meaning that as a sample is being collected, the previous sample is being injected. In the syringe pump module, there is another set of syringes (volume $=2.5 \mathrm{~mL}$ ) for an internal standard. The internal standard containing $\mathrm{Li}^{+}$and $\mathrm{Br}^{-}$is injected simultaneously with the sample and is subsequently mixed with the sample (see the Supplement for additional information on the preparation of this chemical and all other chemicals used for the MARGA). The samples are analyzed using cation and anion ion conductivity detectors (IC, Metrohm USA, Inc., Riverview, FL, USA). For the cation chromatography, the MARGA uses a $500 \mu \mathrm{L}$ injection loop and a Metrosep C4 $150 \mathrm{~mm}$ column (Metrohm USA, Inc.) in conjunction with a $\mathrm{HNO}_{3}$ cation eluent. For the anion chromatography, a $130 \mu \mathrm{L}$ injection loop and a Metrosep A Supp$1075 \mathrm{~mm}$ column (Metrohm USA, Inc.) are used in conjunction with an anion eluent made up of a mixture of sodium carbonate $\left(\mathrm{Na}_{2} \mathrm{CO}_{3}\right)$ and sodium bicarbonate $\left(\mathrm{NaHCO}_{3}\right)$. The signal-to-noise ratio for anion chromatography is improved by suppressing the eluent background conductivity. Three ion exchange units housed within a suppressor module are rotated during each cycle, ensuring that each analysis is conducted with a regenerated ion exchange unit. Phosphoric acid $\left(\mathrm{H}_{3} \mathrm{PO}_{4}\right)$ is used to regenerate the ion exchange units.

\section{Quality assurance/quality control (QA/QC)}

During the ETV test, the MUs air flow rates were verified weekly by measuring the flow rate at the atmospheric inlet using a NIST (National Institute of Standards and Technology) traceable primary standard (DryCal DC-LITE flowmeter, Bios International Corporation, Butler, NJ, USA). Additionally, the MUs inlets and air sampling tubing were cleaned weekly with DDI water and dried with zero grade air. After the completion of the ETV test, a liquid blank was analyzed by running the MUs with the air pumps disconnected and the denuder inlets sealed, thus meaning that the MUs were only sampling the absorption solution. Also with the air pumps disconnected and the denuder inlets sealed, an external standard test was conducted by replacing the absorption solution with a known liquid standard containing $\mathrm{SO}_{4}^{2-}, \mathrm{NH}_{4}^{+}$, and $\mathrm{NO}_{3}^{-}$(additional information on the preparation of the external standard is provided in the Supplement). This was done to verify the analytical accuracy as controlled by the internal lithium bromide $(\mathrm{LiBr})$ standard.

\subsubsection{Denuder-filter pack}

\section{Description of denuder/filter pack system}

The reference methodology was based on compendium method IO-4.2 (US EPA, 1999). Ambient air was sampled by drawing in air at a flow rate of $10 \mathrm{~L} \mathrm{~min}^{-1}$ through an inlet cyclone made of Teflon-coated aluminium with a particle size cutoff of $2.5 \mu \mathrm{m}$, and then through a series of denuders and filters. Samples were collected every $12 \mathrm{~h}$. Two denuders were used in series, the first one coated with $\mathrm{Na}_{2} \mathrm{CO}_{3}$ to collect acid gases (i.e., $\mathrm{SO}_{2}$ and $\mathrm{HNO}_{3}$ ), and the second coated with phosphorus acid $\left(\mathrm{H}_{3} \mathrm{PO}_{3}\right)$ to collect basic gases (i.e., $\mathrm{NH}_{3}$ ). This was followed by a Teflon filter for the collection of particles. Behind the Teflon filter was a nylon filter, which collects volatilized $\mathrm{HNO}_{3}^{-}$from the disassociation of $\mathrm{NH}_{4} \mathrm{NO}_{3}$. Total $\mathrm{NO}_{3}^{-}$filter pack concentrations were the sum of the equivalent $\mathrm{NO}_{3}^{-}$collected on the Teflon and nylon filters. $\mathrm{NO}_{3}^{-}$collected on the nylon filter was also used to calculate total $\mathrm{NH}_{4}^{+}$filter pack concentrations. This was done by adding the $\mathrm{NH}_{4}^{+}$molar equivalent of the $\mathrm{NO}_{3}^{-}$concentration on the nylon filter to the Teflon filter $\mathrm{NH}_{4}^{+}$concentration. 
The temperature of the denuder/filter pack system was partly regulated by a fan. $\mathrm{NH}_{3}$ and $\mathrm{NH}_{4}^{+}$denuder/filter pack samples were analyzed by automated colorimetry based on EPA method 350.1 (US EPA, 1993a). For $\mathrm{HNO}_{3}, \mathrm{NO}_{3}^{-}, \mathrm{SO}_{2}$ and $\mathrm{SO}_{4}^{2-}$, the denuder/filter pack samples were analyzed by ion chromatography based on EPA method 300.0 (US EPA, 1993b).

\section{Quality assurance/quality control (QA/QC)}

During every week of sampling, one set of denuders and filter packs (i.e., one sample) were reserved as trip blanks. The trip blanks were kept in their shipping containers (i.e., they were not handled in the field). However, they were extracted and analyzed like other denuder/filter pack samples. The denuder/filter pack flow rates were verified periodically by a NIST traceable flow transfer standard (DryCal DC-LITE flowmeter, Bios International Corporation, Butler, NJ, USA) and a dry gas meter. Analytical methods were evaluated by using NIST traceable standard solutions. The solutions were prepared to contain concentrations within the range observed during the ETV test. In addition, a set of duplicate samples and calibration check standards were analyzed for every batch of samples analyzed in the laboratory.

\subsection{Methodology used for evaluation of the MARGA}

In this assessment, measurement of the following gases and aerosols by the MARGA was evaluated: $\mathrm{SO}_{2}, \mathrm{HNO}_{3}, \mathrm{NH}_{3}$, $\mathrm{SO}_{4}^{2-}, \mathrm{NO}_{3}^{-}$, and $\mathrm{NH}_{4}^{+}$. The MUs were evaluated for precision and accuracy. Precision was evaluated by calculating the median absolute relative percent difference (MARPD) between paired hourly results from the duplicate MUs. Thus the ARPD was calculated as

$\mathrm{ARPD}=\frac{\left|C(\mathrm{MU} 1)_{i}-C(\mathrm{MU} 2)_{i}\right|}{\left[C(\mathrm{MU} 1)_{i}+C(\mathrm{MU} 2)_{i}\right] / 2} \times 100$,

where $C(\mathrm{MU} 1)_{i}$ and $C(\mathrm{MU} 2)_{i}$ are air concentrations measured by each of the MUs for the $i$ th sampling period. From this, the median value of the ARPD values was used. The precision goal for each compound was to have a MARPD $\leq 25 \%$.

The accuracy of the MUs was evaluated in comparison to the denuder/filter pack system. As stated, the MARGA measures at an hourly temporal resolution. Therefore, $1 \mathrm{~h}$ MU data were averaged to $12 \mathrm{~h}$ for comparison to the denuder/filter pack. The accuracy of the MUs was evaluated by calculating the ARPD for each MU relative to the average of the duplicate denuder/filter pack concentrations. The ARPD was calculated as

$\mathrm{ARPD}=\left|\frac{C_{i}-\overline{C(\mathrm{~d} / \mathrm{f})_{i}}}{\overline{C(\mathrm{~d} / \mathrm{f})_{i}}}\right| \times 100$,

where $C_{i}$ is the $12 \mathrm{~h}$ averaged concentration measured by a MU and $C(\mathrm{~d} / \mathrm{f})_{i}$ is the mean concentration of the dupli- cate denuder/filter pack samples for the $i$ th sampling period. From this, the median value of the ARPD values was used. The accuracy goal for each compound was to have a MARPD $\leq 40 \%$. In addition, accuracy was evaluated by linear regression; i.e., the $12 \mathrm{~h}$ averaged concentrations of each MU were plotted against the average of the corresponding duplicate denuder/filter pack concentrations. From this, a linear least squares line of best fit was applied. The goal was for the slope of the line of best fit to be between 0.8 and 1.2.

\section{Results and discussion}

\subsection{Raw data adjustments}

Raw MU air concentration data were adjusted based on differences between the measured and recorded air flow rates, liquid blanks, and biases in calibration standard checks. The average measured flow rates were $16.48 \mathrm{~L} \mathrm{~min}^{-1}$ for MARGA unit 1 (MU1) and $15.98 \mathrm{~L} \mathrm{~min}^{-1}$ for MARGA unit 2 (MU2). The MARGA calculates concentrations using a flow rate of $16.7 \mathrm{~L} \mathrm{~min}^{-1}$; therefore the raw data concentrations were adjusted upward by $1.4 \%$ for MU1 and by $4.5 \%$ for MU2. The results of the liquid blanks, external standards, and the analytical bias are presented in the Supplement. Liquid blanks for all the species $\left(\mathrm{SO}_{2}, \mathrm{SO}_{4}^{2-}, \mathrm{HNO}_{3}\right.$, $\mathrm{NO}_{3}^{-}, \mathrm{NH}_{3}$, and $\mathrm{NH}_{4}^{+}$) ranged from 0 to $0.15 \mu \mathrm{g} \mathrm{m}^{-3}$ for both MU1 and MU2. The analytical bias (after subtracting the liquid blank concentration) for $\mathrm{SO}_{2}, \mathrm{SO}_{4}^{2-}, \mathrm{HNO}_{3}$, and $\mathrm{NO}_{3}^{-}$ was acceptable, ranging from +4.5 to $+11.2 \%$ for MU1 and +3.5 to $+10.7 \%$ for MU2. The analytical bias for $\mathrm{NH}_{3}$ and $\mathrm{NH}_{4}^{+}$was not as good, with values ranging from -22.7 to $-14.5 \%$ for MU1 and -24.4 to $-21.1 \%$ for MU2. The $\mathrm{SO}_{2}, \mathrm{SO}_{4}^{2-}, \mathrm{HNO}_{3}$, and $\mathrm{NO}_{3}^{-}$measurements were adjusted for their respective analytical biases. However, the bias adjustment of $\mathrm{NH}_{3}$ and $\mathrm{NH}_{4}^{+}$was not as straightforward. Consequently, details of the bias correction for these compounds are presented in the discussion of the $\mathrm{NH}_{4}^{+}$and $\mathrm{NH}_{3}$ results (Sects. 3.4.5 and 3.4.6, respectively).

Denuder-filter pack concentrations were adjusted by subtracting the average concentration of six trip blanks (table of results is provided in the Supplement). Blank values were close to or under the detection limit (DL) for all the compounds apart from $\mathrm{NH}_{3}$, which had a high and variable blank, with an average value of $1.38 \pm 0.43 \mu \mathrm{g}$. In addition, it should be noted that the laboratory QA/QC results showed very good performance of the analytical instruments. More information on the results of the laboratory QA/QC procedures can be found in the corresponding ETV report (US EPA, 2011).

\subsection{Data collection and detection limits}

A summary of the data collection over the 30-day ETV period for the MUs and the denuder/filter pack is presented in Table 1. With respect to data completeness, the MUs 
Table 1. Summary of data collection and detection limits for each compound and for each measurement system.

\begin{tabular}{|c|c|c|c|c|c|c|c|c|}
\hline & & & \multicolumn{3}{|c|}{$1 \mathrm{~h}$ data } & \multicolumn{3}{|c|}{$12 \mathrm{~h}$ data } \\
\hline & & $\begin{array}{l}\text { Detection limit } \\
\left(\mu \mathrm{g} \mathrm{m}^{-3}\right)\end{array}$ & $\begin{array}{l}\text { Number } \\
\text { of data } \\
\text { points }^{\mathrm{a}}\end{array}$ & $<\mathrm{DL}$ & $<2 \mathrm{DL}$ & $\begin{array}{l}\text { Number } \\
\text { of data } \\
\text { points }^{b}\end{array}$ & $<\mathrm{DL}$ & $<2 \mathrm{DL}$ \\
\hline \multirow{3}{*}{$\mathrm{SO}_{2}$} & MU 1 & 0.05 & 716 & 671 & 619 & 60 & 59 & 58 \\
\hline & MU 2 & & 694 & 653 & 612 & 60 & 59 & 57 \\
\hline & Denuder & $0.08^{\mathrm{c}}$ & - & - & - & 120 & 120 & 117 \\
\hline \multirow{3}{*}{$\mathrm{SO}_{4}^{2-}$} & MU 1 & 0.08 & 716 & 716 & 705 & 60 & 60 & 59 \\
\hline & MU 2 & & 692 & 689 & 676 & 60 & 60 & 59 \\
\hline & Teflon filter & 0.15 & - & - & - & 120 & 118 & 114 \\
\hline \multirow{3}{*}{$\mathrm{HNO}_{3}$} & MU 1 & 0.10 & 716 & 665 & 599 & 60 & 59 & 55 \\
\hline & MU 2 & & 694 & 654 & 564 & 60 & 59 & 54 \\
\hline & Denuder & 0.11 & - & - & - & 120 & 117 & 102 \\
\hline \multirow{4}{*}{$\mathrm{NO}_{3}^{-}$} & MU 1 & 0.10 & 716 & 649 & 545 & 60 & 59 & 48 \\
\hline & MU 2 & & 692 & 634 & 492 & 60 & 57 & 45 \\
\hline & Teflon filter & 0.13 & - & - & - & 120 & 52 & 14 \\
\hline & Nylon filter & 0.13 & - & - & - & 120 & 81 & 23 \\
\hline \multirow{3}{*}{$\mathrm{NH}_{3}$} & MU 1 & 0.05 & 716 & 716 & 716 & 60 & 60 & 60 \\
\hline & MU 2 & & 694 & 694 & 694 & 60 & 60 & 60 \\
\hline & Denuder & 0.07 & - & - & - & 120 & 119 & 117 \\
\hline \multirow{3}{*}{$\mathrm{NH}_{4}^{+}$} & MU 1 & 0.05 & 716 & 716 & 716 & 60 & 60 & 60 \\
\hline & MU 2 & & 693 & 693 & 693 & 60 & 60 & 60 \\
\hline & Teflon filter & 0.09 & - & - & - & 120 & 114 & 112 \\
\hline
\end{tabular}

a Maximum number of hourly data points that could be collected was 720 .

b Maximum number of $12 \mathrm{~h}$ data points that could be collected was 60 for each MU, and 120 for the duplicate filter denuder systems combined

${ }^{\mathrm{c}}$ Estimated concentration detection limits calculated using the mass detection limit and the average denuder/filter pack flow rate during the ETV test.

performed extremely well over the ETV period, collecting valid $1 \mathrm{~h}$ data $\approx 98 \%$ of the time. For MU1, the only loss of data occurred when the inlet was cleaned and the air flow rate checked. MU2 had an occasionally reoccurring hardware and software problem, which was responsible for almost all of the additional invalid data. As mentioned, to compare the MARGA data to the denuder/filter pack, the MARGA $1 \mathrm{~h}$ data were averaged into $12 \mathrm{~h}$ averages. None of the data loss events were longer than $5 \mathrm{~h}$; therefore all $12 \mathrm{~h}$ averages were based on a minimum of 7 full hours of data and were included in the data analysis. All 120 samples collected from the denuder/filter pack systems were successfully collected and analyzed.

The number of sample results greater than the detection limit (DL) and greater than twice the detection limit (2DL) for each target analyte are also provided in Table 1. MARGA detection limits were determined by using 4 times the noise of the anion and cation IC detector signal. For the MUs, all $\mathrm{NH}_{3}$ and $\mathrm{NH}_{4}^{+}$averages were greater than 2DL. No $12 \mathrm{~h}$ and $\approx 0.2 \%$ of $1 \mathrm{~h} \mathrm{SO}_{4}^{2-}$ average concentrations were below the DL. Approximately $2 \%$ of both $1 \mathrm{~h}$ and $12 \mathrm{~h} \mathrm{MU} \mathrm{SO}_{4}^{2-}$ concentrations were below $2 \mathrm{DL}$. $\mathrm{SO}_{2}$ and $\mathrm{HNO}_{3}$ concentrations were closer to their detection limits, with $\approx 6 \%(1 \mathrm{~h})$ or $2 \%$
$(12 \mathrm{~h})$ of collected $\mathrm{MU} \mathrm{SO} 2$ data below the $\mathrm{DL}$ and $\approx 13 \%$ $(1 \mathrm{~h})$ or $4 \%(12 \mathrm{~h})$ below $2 \mathrm{DL} . \mathrm{HNO}_{3}$ had $\approx 6 \%$ (1 h) or $2 \%$ ( $12 \mathrm{~h}$ ) of MU concentration data below the DL. Approximately $18 \%(1 \mathrm{~h})$ or $9 \%(12 \mathrm{~h})$ of $\mathrm{MU} \mathrm{HNO}_{3}$ concentrations were below 2DL. Out of the compounds measured by the MARGA for this study, $\mathrm{NO}_{3}^{-}$concentrations were closest to their DL, with $\approx 9 \%(1 \mathrm{~h})$ or $4 \%(12 \mathrm{~h})$ below the DL and $27 \%(1 \mathrm{~h})$ or $22 \%(12 \mathrm{~h})$ of MU concentrations below 2DL.

For the denuder/filter pack, very few (from zero to $7 \%$ ) of the $\mathrm{SO}_{2}, \mathrm{SO}_{4}^{2-}, \mathrm{NH}_{3}$, and $\mathrm{NH}_{4}^{+}$concentrations were below either the DL or 2DL (Table 1). For $\mathrm{HNO}_{3}, \approx 3 \%$ of concentrations were below the DL, and $15 \%$ were below 2DL. For the filter pack, $\mathrm{NO}_{3}^{-}$had by far the most concentrations below the DL and 2DL. For the Teflon filter, $\approx 57 \%$ of $\mathrm{NO}_{3}^{-}$concentrations were below the DL and $88 \%$ were below 2DL. The nylon filter had $\approx 33 \%$ of concentrations below the DL and $\approx 81 \%$ below $2 \mathrm{DL}$. For the data analysis, the measured concentration values were used. The high percentage of $\mathrm{NO}_{3}^{-}$filter pack concentrations around or below the DL should be taken into consideration when evaluating the performance of the MARGA for $\mathrm{NO}_{3}^{-}$. A brief analysis of $\mathrm{NO}_{3}^{-}$volatilization from the Teflon filter is provided in the Supplement. 
a)

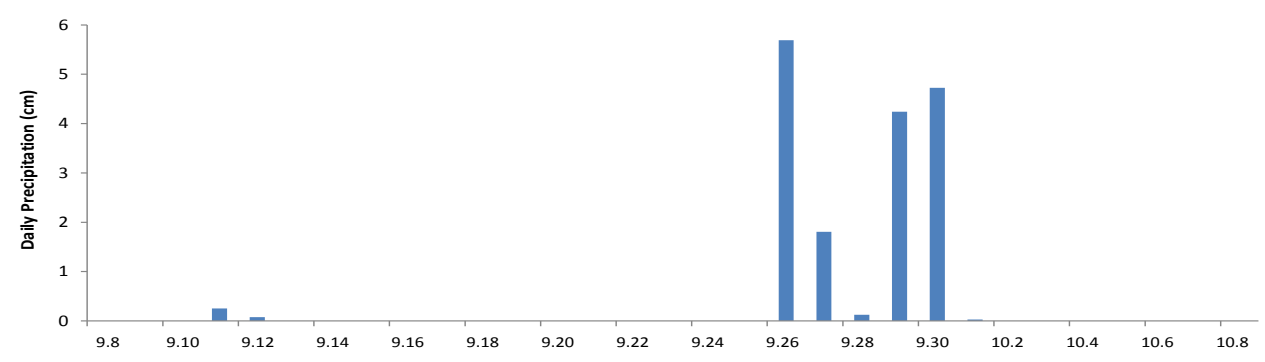

b)

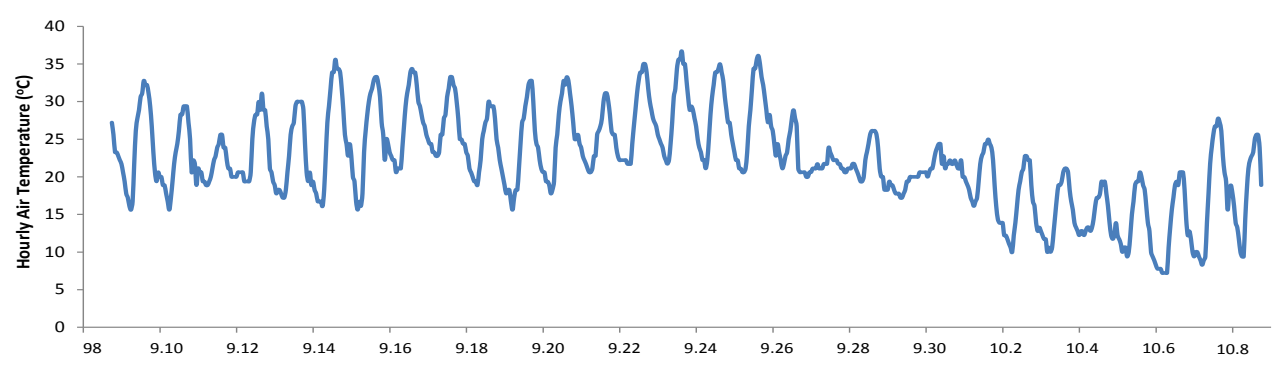

Figure 1. (a) Daily precipitation and (b) hourly air temperature at RDU airport $(\approx 8 \mathrm{~km}$ from sampling site) during the ETV period $(8$ September 2010-8 October 2010).

\subsection{Meteorological conditions during the ETV period}

The meteorological conditions during the ETV period varied significantly. Fig. 1a and b present precipitation and air temperature, respectively, at Raleigh-Durham (RDU) airport (approximately $8 \mathrm{~km}$ from the sampling site). From 8 September to 25 September the meteorological conditions are characterized as hot and dry, with daily maximum hourly temperatures generally above $30^{\circ} \mathrm{C}$ and no precipitation apart from small amounts on 11 and 12 September. From 26 to 30 September, the temperatures were cooler (hourly temperatures varying from 17 to $26^{\circ} \mathrm{C}$ ) and wet with $\approx 16.5 \mathrm{~cm}$ of total precipitation during the period. Following the rain event, conditions were again dry with maximum hourly temperatures between 18 to $26^{\circ} \mathrm{C}$.

\subsection{Evaluation of measured MARGA aerosol and gas concentrations}

\subsection{1 $\mathrm{SO}_{4}^{2-}$}

The $\mathrm{SO}_{4}^{2-}$ concentration trends for the MUs and the filter pack are presented in Fig. 2. Both the MUs and the filter pack measured similar $\mathrm{SO}_{4}^{2-}$ concentrations during the ETV period. $\mathrm{SO}_{4}^{2-}$ concentrations were generally higher before the rain event of 26 to 30 September, with the period from 22 to 24 September having the highest concentrations. During the rain event, concentrations decreased and then stayed low. Subsequently, concentrations generally increased to the end of the ETV period. The mean filter pack $\mathrm{SO}_{4}^{2-}$ con- centration was $2.40 \mu \mathrm{g} \mathrm{m}^{-3} \pm 1.41$ (1 standard deviation). The MU mean $\mathrm{SO}_{4}^{2-}$ concentrations were slightly higher, at $2.63 \mu \mathrm{g} \mathrm{m}^{-3} \pm 1.38$ and $2.57 \mu \mathrm{g} \mathrm{m}^{-3} \pm 1.38$ for MU1 and MU2, respectively.

The MARGA performed well for $\mathrm{SO}_{4}^{2-}$, passing all precision and accuracy goals. The precision between the MUs was excellent for $\mathrm{SO}_{4}^{2-}$, with a MARPD of $3.2 \%$. The accuracy of $\mathrm{SO}_{4}^{2-}$ was also excellent, with slope values for the regression analysis of 0.97 and 0.98 for MU1 and MU2, respectively (Fig. 3). The accuracy was also very good, with values of $12.7 \%$ MARPD for MU1 and $7.3 \%$ MARPD for MU2. The good performance of the MUs in measuring $\mathrm{SO}_{4}^{2-}$ is supported by the study by Makkonen et al. (2012), which also compared measured MARGA concentrations to those from a Teflon filter using linear regression and reported a slope value of 0.85 for $\mathrm{SO}_{4}^{2-}$.

\subsection{2 $\mathrm{SO}_{2}$}

The measured $\mathrm{SO}_{2}$ concentration trends during the ETV period are presented in Fig. 4. Both the denuder and the MUs measured similar $\mathrm{SO}_{2}$ concentrations during the ETV period. Generally, $\mathrm{SO}_{2}$ concentrations were higher before the rain event on 26 September, with the highest measured concentration occurring on 16 September. After the beginning of the rain event, concentrations decreased rapidly and stayed low until almost the end of the ETV period (7 October), when concentrations started to increase. The average $\mathrm{SO}_{2}$ concentration measured during the ETV by the denuder system was $2.08 \mu \mathrm{g} \mathrm{m}^{-3} \pm 2.64$. MU concentrations were slightly 


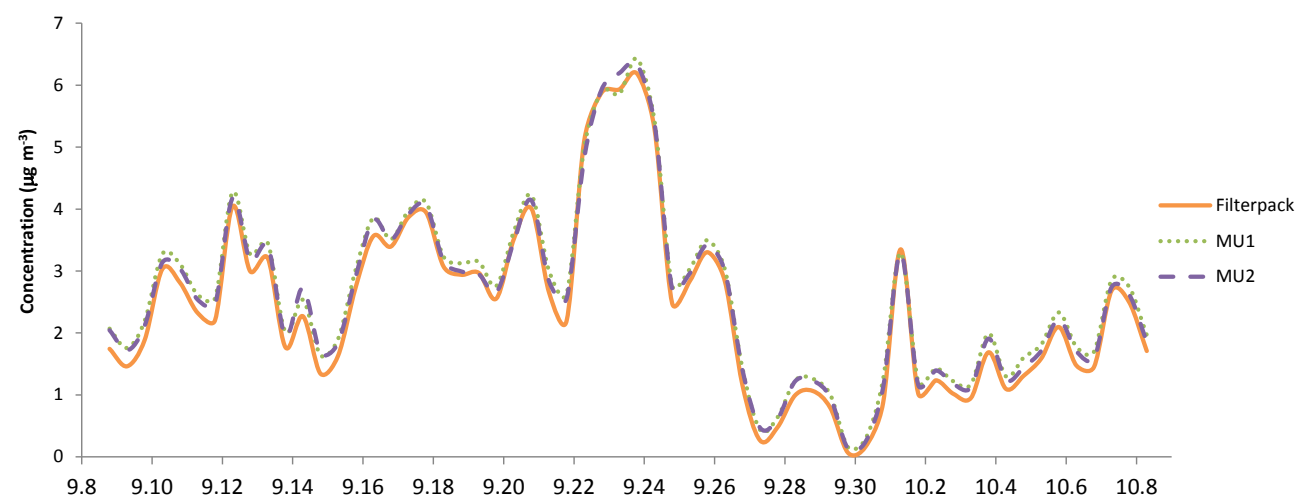

Figure 2. Filter pack and MU measured $\mathrm{SO}_{4}^{2-}$ concentrations during the ETV period.

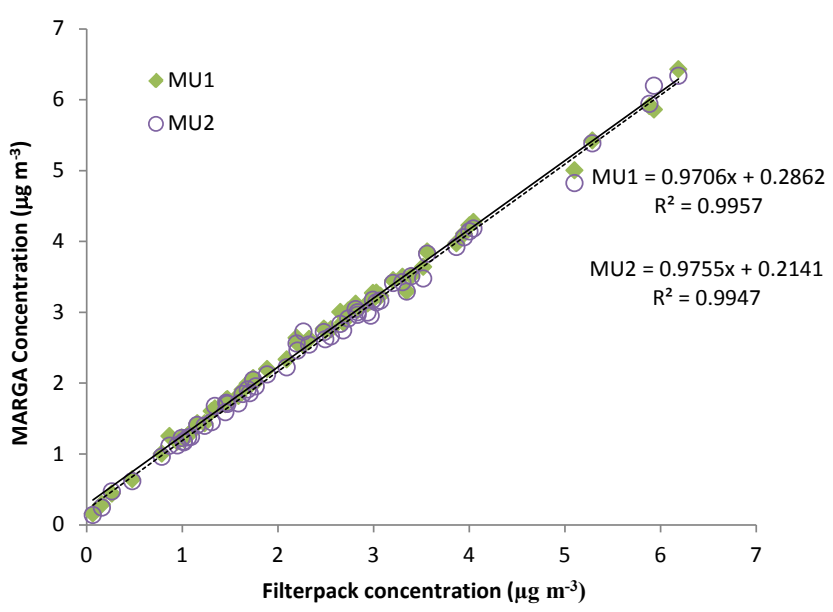

Figure 3. Regression analysis of MARGA $\mathrm{SO}_{4}^{2-}$ concentrations against filter pack $\mathrm{SO}_{4}^{2-}$ concentrations.

higher, with MU1 having an average $\mathrm{SO}_{2}$ concentration of $2.38 \mu \mathrm{g} \mathrm{m}^{-3} \pm 2.94$ and MU2 having an average concentration of $2.20 \mu \mathrm{g} \mathrm{m}^{-3} \pm 2.79$.

Overall, the MARGA performed well for $\mathrm{SO}_{2}$, passing all precision and accuracy goals. The MARPD between the MUs was $11.5 \%$, which is well within the precision goal of $25 \%$. The MUs performed well in comparison to denuder and PFA measurement techniques. For details on the performance of the MUs in comparison to the $\mathrm{SO}_{2} \mathrm{PFA}$, the reader is referred to the Supplement. Against $12 \mathrm{~h}$ denuder concentrations (Fig. 5), the slope values were 1.11 for MU1 and 1.05 for MU2, which are well within the accuracy goal of 0.8 to 1.2. The MARPD between the MARGA $\mathrm{SO}_{2}$ concentrations and denuder concentrations was $20.3 \%$ for MU1, and $10.9 \%$ for MU2, which is well within the accuracy goal of $40 \%$. Measured MARGA $\mathrm{SO}_{2}$ concentrations were compared to those measured by a TEI 43iTL $\mathrm{SO}_{2}$ monitor in a study by Makkonen et al. (2012). Similarly to this study, the MARGA compared well with a linear regression slope of 0.90 .

\subsection{3 $\mathrm{NO}_{3}^{-}$}

The $\mathrm{NO}_{3}^{-}$concentration trends during the ETV period are presented in Fig. 6. The MUs and the filter pack showed a similar concentration pattern. However, there was a large difference in the $\mathrm{NO}_{3}^{-}$concentrations measured by the MUs and the filter pack and also between the MUs. The concentrations measured by MU1 were higher than MU2 for almost the entire ETV period. Likewise, MU2 concentrations were almost always higher than the filter pack over the ETV period. The largest difference in measured concentrations occurred when there were peaks in concentration. In the period from 8 until 20 September the $\mathrm{NO}_{3}^{-}$concentrations for all the instruments fluctuated, with the highest peaks occurring on 11 September. On 21 September, there was a rapid increase in $\mathrm{NO}_{3}^{-}$for both MUs, and $\mathrm{MU} \mathrm{NO} \mathrm{NO}_{3}^{-}$concentrations were then consistently high until 25 September. The increase on 21 September is much smaller for the filter pack; however the pattern is very similar. After the beginning of the rain event on 26 September, there was a rapid decrease in $\mathrm{NO}_{3}^{-}$concentrations, and concentrations then stayed low until almost the end of the ETV period (6 October). During the 26 September to 6 October period, the MUs and the filter pack concentrations were the most similar. On 7 October there was a large $\mathrm{NO}_{3}^{-}$ peak for MU1, and as with the other $\mathrm{NO}_{3}^{-}$peaks this peak was smaller for MU2 and smaller still for the filter pack. The average $\mathrm{NO}_{3}^{-}$concentration during the ETV for MU1 was $0.53 \mu \mathrm{g} \mathrm{m}^{-3} \pm 0.38$, which was higher than the MU2 average concentration of $0.41 \mu \mathrm{g} \mathrm{m}^{-3} \pm 0.28$. Both MU average concentrations were higher than the filter pack, which had an average concentration of $0.32 \mu \mathrm{g} \mathrm{m}^{-3} \pm 0.14$.

In an initial comparison to the filter pack, the MUs apparently performed poorly for $\mathrm{NO}_{3}^{-}$, passing only one of the accuracy goals and not the precision goal. The linear regression analysis for $\mathrm{NO}_{3}^{-}$(Fig. 7) shows both slopes to be well above the slope goal of 1.2 , with values of 2.36 and 1.73 for MU1 and MU2, respectively. In comparison to the filter pack, the MARPD for MU1 was $43.1 \%$, which is just above the MARPD accuracy goal. The MARPD for MU2, however, 


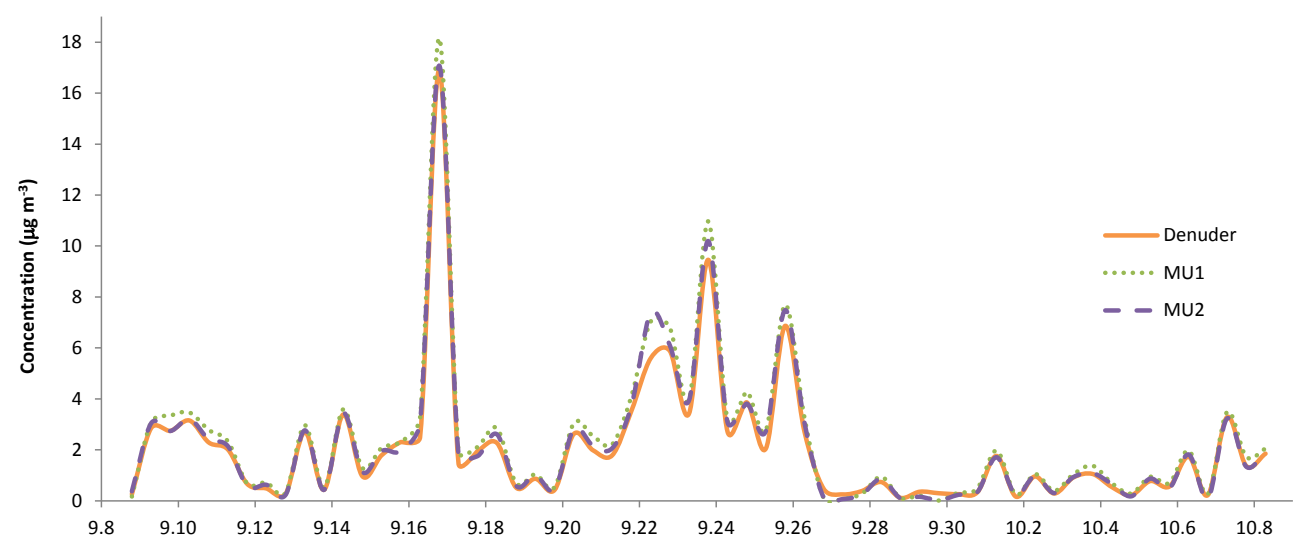

Figure 4. Denuder and MU measured $\mathrm{SO}_{2}$ concentrations during the ETV period.

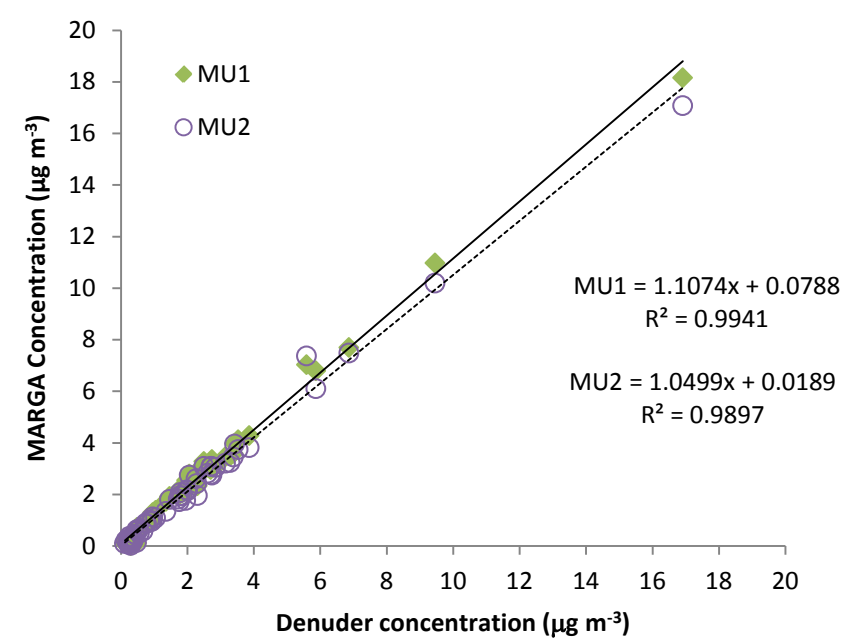

Figure 5. Regression analysis of MARGA $\mathrm{SO}_{2}$ concentrations against denuder $\mathrm{SO}_{2}$ concentrations.

was within the accuracy goal, with a value of $30.7 \%$. The MARPD between the MUs was $30.8 \%$, which is marginally above the precision goal.

After further investigation, the poor agreement between the MUs and the filter pack for $\mathrm{NO}_{3}^{-}$was found to be the result of the different sampling efficiency of coarse $\mathrm{NO}_{3}^{-}$by the MUs and the filter pack. As mentioned in Sect. 2.2, the filter pack had a particle size cutoff of $2.5 \mu \mathrm{m}$ (aerodynamic diameter), whereas the MARGA customized inlet had a cutoff of $\approx 26 \mu \mathrm{m}$. The explanation for the difference between the MUs is related to the performance of the inlets. As mentioned, the inlet cutoff is determined by inertial separation (a schematic of the inlet is provided in the Supplement). It is hypothesized that the fans controlling the bypass flow rate through the inlets on MU1 and MU2 were operating at different speeds and thus creating different particle size cutoff points for the MUs. The evidence for the different sampling efficiency of coarse $\mathrm{NO}_{3}^{-}$can be observed through the exam- ination of $\mathrm{NO}_{3}^{-}$and the cation species expected to be associated with coarse particle $\mathrm{NO}_{3}^{-}$. Figure 8 shows the concentration trend of $\mathrm{NO}_{3}^{-}$during the ETV period and the concentration trends of three compounds that are often components of coarse $\mathrm{NO}_{3}^{-}$aerosols, sodium (Na), magnesium $(\mathrm{Mg})$, and calcium $(\mathrm{Ca})$. Sodium nitrate $\left(\mathrm{NaNO}_{3}\right)$ and magnesium nitrate $\left(\mathrm{Mg}\left(\mathrm{NO}_{3}\right)_{2}\right)$ can form through the reaction of nitric acid with sodium and magnesium in sea-salt particles (Gibson et al., 2006).

$$
\begin{aligned}
& \mathrm{NaCl}_{(\mathrm{a})}+\mathrm{HNO}_{3(\mathrm{~g})} \rightarrow \mathrm{NaNO}_{3(\mathrm{a})}+\mathrm{HCl}_{(\mathrm{g})} \\
& \mathrm{MgCl}_{2(\mathrm{a})}+2 \mathrm{HNO}_{3} \rightarrow \mathrm{Mg}\left(\mathrm{NO}_{3}\right)_{2}+2 \mathrm{HCl}_{(\mathrm{g})}
\end{aligned}
$$

Calcium and magnesium are components of mineral dust such as calcium carbonate $\left(\mathrm{CaCO}_{3}\right)$ and dolomite $\left(\mathrm{CaMg}\left(\mathrm{CO}_{3}\right)_{2}\right)$ and can also react with nitric acid to form calcium nitrate $\left(\mathrm{Ca}\left(\mathrm{NO}_{3}\right)_{2}\right)$ and $\mathrm{Mg}\left(\mathrm{NO}_{3}\right)_{2}$ (Gibson et al., 2006).

$\mathrm{CaCO}_{3(\mathrm{a})}+2 \mathrm{HNO}_{3(\mathrm{~g})} \rightarrow$
$\mathrm{Ca}\left(\mathrm{NO}_{3}\right)_{2(\mathrm{a})}+\mathrm{H}_{2} \mathrm{O}+\mathrm{CO}_{2(\mathrm{~g})}$
$\mathrm{CaMg}\left(\mathrm{CO}_{3}\right)_{2(\mathrm{a})}+4 \mathrm{HNO}_{3(\mathrm{~g})} \rightarrow \mathrm{Ca}\left(\mathrm{NO}_{3}\right)_{2(\mathrm{a})}$
$+\mathrm{Mg}\left(\mathrm{NO}_{3}\right)_{2(\mathrm{a})}+2 \mathrm{H}_{2} \mathrm{O}+2 \mathrm{CO}_{2(\mathrm{~g})}$

The influence of coarse $\mathrm{NO}_{3}^{-}$on total $\mathrm{NO}_{3}^{-}$measured by the MUs can be observed by comparing the coarse cation component concentrations to the corresponding measured $\mathrm{NO}_{3}^{-}$concentrations, in particular where there are concentrations peaks (Fig. 8). For example, for $\mathrm{Na}^{+}$, the largest peaks occur on 15, 17, 21, and 25 September. For all these peaks, there is a large difference in measured $\mathrm{Na}^{+}$concentrations between the instruments, with MU1 measuring higher concentrations than MU2 and MU2 measuring higher concentrations than the filter pack. During the same time periods there are also similar differences in measured concentrations for $\mathrm{Mg}^{2+}$. However, the $\mathrm{Mg}^{2+}$ concentrations are much smaller than those of $\mathrm{Na}^{+}$. For $\mathrm{Mg}^{2+}$, there is also a large difference in measured concentrations between the instruments for 


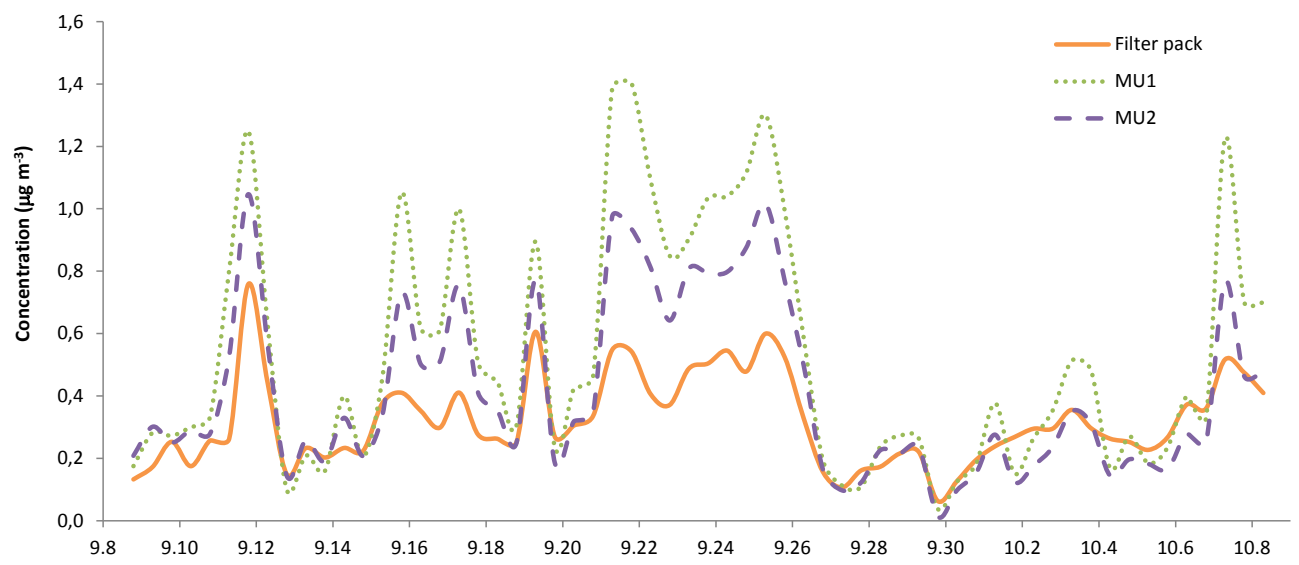

Figure 6. Filter pack and $\mathrm{MU}$ measured $\mathrm{NO}_{3}^{-}$concentrations during the ETV period.

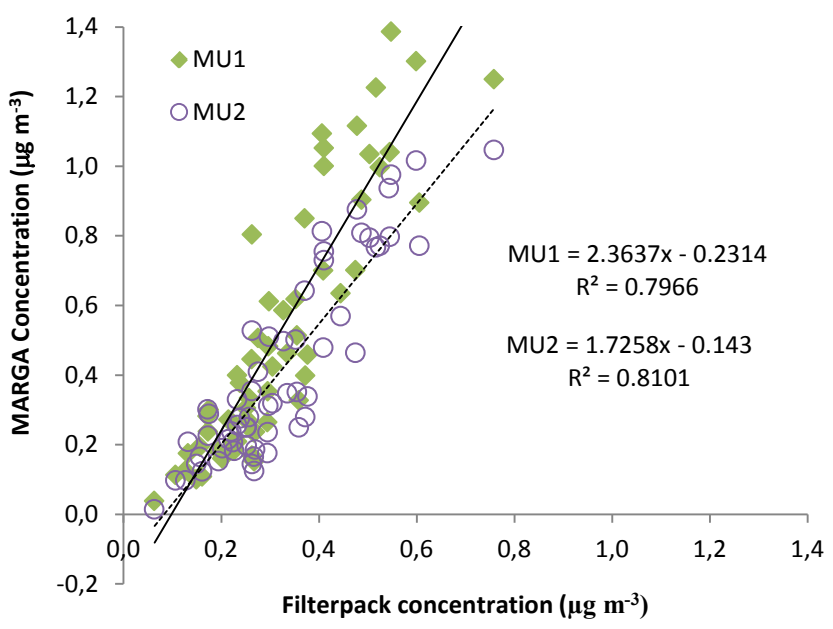

Figure 7. Regression analysis of MARGA $\mathrm{NO}_{3}^{-}$concentrations against filter pack $\mathrm{NO}_{3}^{-}$concentrations.

a peak on 7 October. The same trend can also be observed on 7 October for $\mathrm{Ca}^{2+}$; however the measured $\mathrm{Ca}^{2+}$ peaks are much larger in magnitude than for $\mathrm{Mg}^{2+}$. Again, during the corresponding time period for $\mathrm{NO}_{3}^{-}$, a similar pattern in measured concentrations between the instruments can be observed.

To further examine the influence of coarse $\mathrm{NO}_{3}^{-}$sampling efficiency on the difference in measured $\mathrm{NO}_{3}^{-}$concentrations, the estimated contribution of coarse $\mathrm{NO}_{3}^{-}$was subtracted from both the MUs and the filter pack. However, this was only done using $\mathrm{Na}^{+}$, because of observed anomalies in the $\mathrm{Ca}^{2+}$ and $\mathrm{Mg}^{2+}$ data. This is evidenced by elevated MU2 $\mathrm{Ca}^{2+}$ concentrations during the rain event period from $\approx 27$ to 30 September (Fig. 8). During this period, almost all other compound concentrations are at zero or near zero. There also appears to be some inaccuracy associated with $\mathrm{Mg}^{2+}$ filter pack measurements. An examination of this concentration trend shows that there are no zero measurements during the
ETV period, even during the rain event, when the concentrations of many other aerosol compounds are zero. As a result of the possible error associated with $\mathrm{Ca}^{2+}$ and $\mathrm{Mg}^{2+}$ concentrations, these compounds were not considered for further analysis. It should be stated that the objectives of the ETV test were to assess the performance of the MARGA in measuring $\mathrm{HNO}_{3}, \mathrm{NO}_{3}^{-}, \mathrm{NH}_{3}, \mathrm{NH}_{4}^{+}, \mathrm{SO}_{2}$, and $\mathrm{SO}_{4}^{2-}$. Therefore it was not a priority of the ETV test to ensure that other compounds such as $\mathrm{Ca}^{2+}$ and $\mathrm{Mg}^{2+}$ were measured accurately.

To evaluate the potential impact of different sampling of coarse $\mathrm{NO}_{3}^{-}$by the instruments, $\mathrm{NaNO}_{3}$ concentrations were subtracted from total $\mathrm{NO}_{3}^{-}$concentrations, yielding an estimate of $\mathrm{NO}_{3}^{-}$that is assumed to represent the "fine" fraction sampled by the MUs and the filter pack. This was done by assuming that all $\mathrm{Na}^{+}$observed was in the form of $\mathrm{NaNO}_{3}$. The results of this adjustment are shown in Fig. 9, which presents the concentration trend, and Fig. 10, which presents the regression analysis. As can be observed in Fig. 9, the concentration trends for $\mathrm{NO}_{3}^{-}$now agree more closely, both in the comparison of MUs to the filter pack and between the MUs. The periods of largest disagreement are from 22 to 26 September and the peak on 7 October, which are the times when there were large $\mathrm{Mg}^{2+}$ and $\mathrm{Ca}^{2+}$ peaks. The linear regression analysis for $\mathrm{NO}_{3}^{-}$(Fig. 10) produces slopes that are much closer to 1, with slopes of 1.28 and 0.82 for MU1 and MU2, respectively. Representative accuracy and precision MARPD could not be calculated with the adjusted $\mathrm{NO}_{3}^{-}$data due to the large number of negative and near-zero concentration values. However, it was concluded that if the MUs and the filter pack were sampling the same particle size, the MUs would have good agreement for $\mathrm{NO}_{3}^{-}$in terms of precision and accuracy. This is supported by the results from Makkonen et al. (2012), in which $\mathrm{NO}_{3}^{-}$measurements were made simultaneously by the MARGA and a Teflon filter, with both measurement systems having the same particle size cutoff of $10 \mu \mathrm{m}$. Linear regression between the measurement systems produced a slope of 0.9 . 

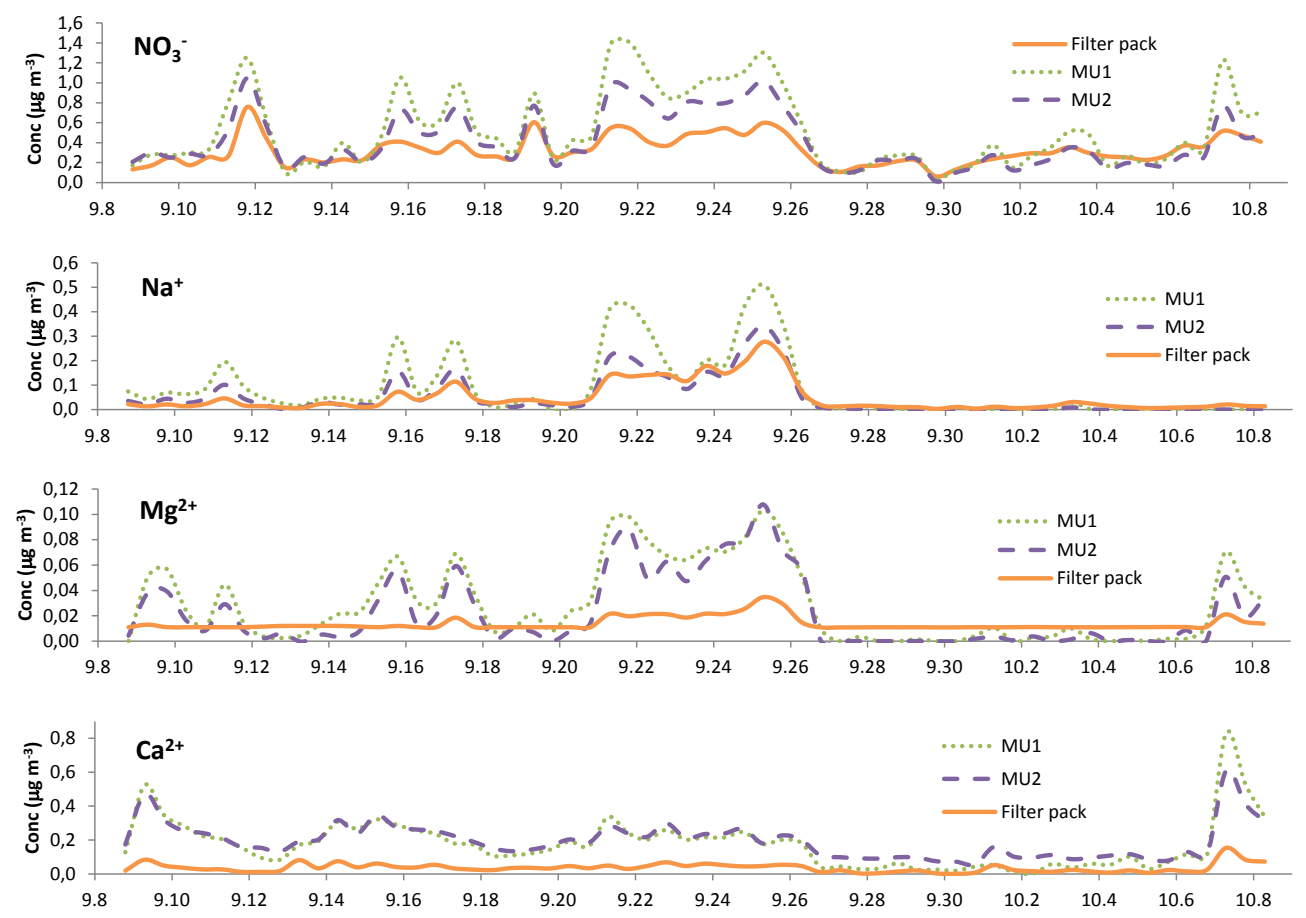

Figure 8. Concentration trends of $\mathrm{NO}_{3}^{-}$and 3 compounds $\left(\mathrm{Na}^{+}, \mathrm{Mg}^{2+}, \mathrm{Ca}^{2+}\right)$ that are often components of the coarse $\mathrm{NO}_{3}^{-}$aerosol.

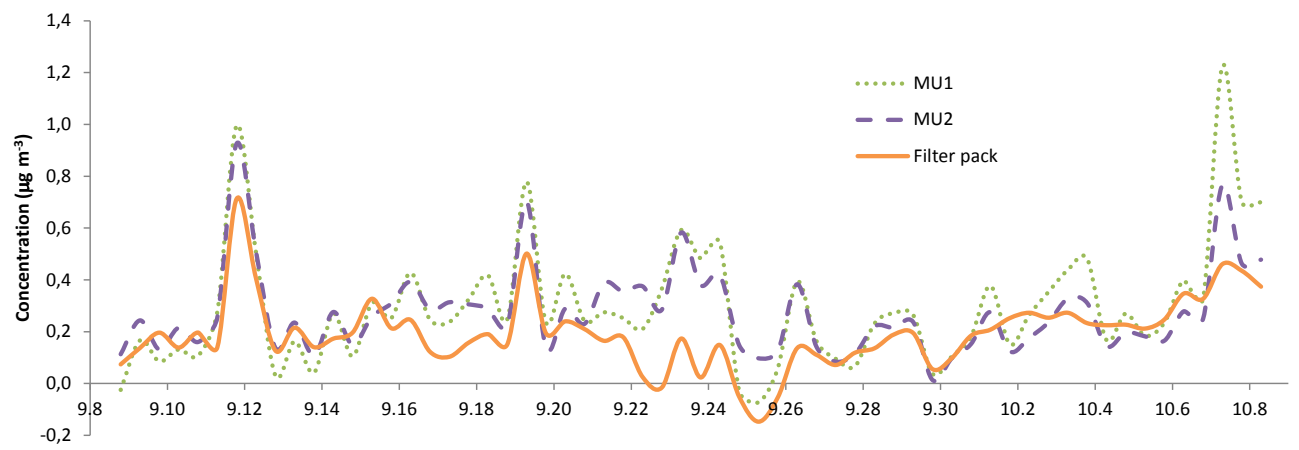

Figure 9. Concentration trends of estimated "fine" $\mathrm{NO}_{3}^{-}$(total $\mathrm{NO}_{3}^{-}$minus $\mathrm{NaNO}_{3}$ ) for the $\mathrm{MUs}$ and filter pack during the ETV period.

\subsection{4 $\mathrm{HNO}_{3}$}

The $\mathrm{HNO}_{3}$ concentration trends for the MUs and the filter pack are presented in Fig. 11. The $\mathrm{HNO}_{3}$ diurnal variation can be observed clearly in these data, with $\mathrm{HNO}_{3}$ concentrations higher during the day as expected. The daytime peaks occur due to the production of the hydroxyl radical $(\mathrm{OH})$ and its subsequent reaction with nitrogen dioxide $\left(\mathrm{NO}_{2}\right)$. A noticeable difference can be observed between the denuder and MARGA concentration trends, with typically the MUs measuring lower concentrations than the denuder during the day, and higher concentrations than the denuder at night. These concentration differences are probably a result of the nature of $\mathrm{HNO}_{3}$, which is a "sticky" gas. It is hypothesized that $\mathrm{HNO}_{3}$ adsorbs onto active sites on the MU inlet and tub- ing. Factors that may affect adsorption include $\mathrm{HNO}_{3}$ concentration, the temperature of the inlet and tubing, and the moisture content of the sample airstream. All of these factors can vary on a diurnal cycle. Prior to the rain event, the daily concentration of $\mathrm{HNO}_{3}$ is fairly consistent, apart from a large peak during the daytime on 15 September. During the rain event, concentrations decreased and remained low. After the rain event, there is a general increase in concentrations until the end of the ETV period. It can be observed that the difference between MARGA and denuder concentrations is less in the post-rain period. The mean denuder concentration was $0.91 \mu \mathrm{g} \mathrm{m}^{-3} \pm 0.79$. The MU1 mean concentration during the ETV period was similar with a value of $0.90 \mu \mathrm{g} \mathrm{m}^{-3} \pm 0.62$. MU2 concentrations were slightly lower with a mean concentration of $0.74 \mu \mathrm{g} \mathrm{m}^{-3} \pm 0.48$. 


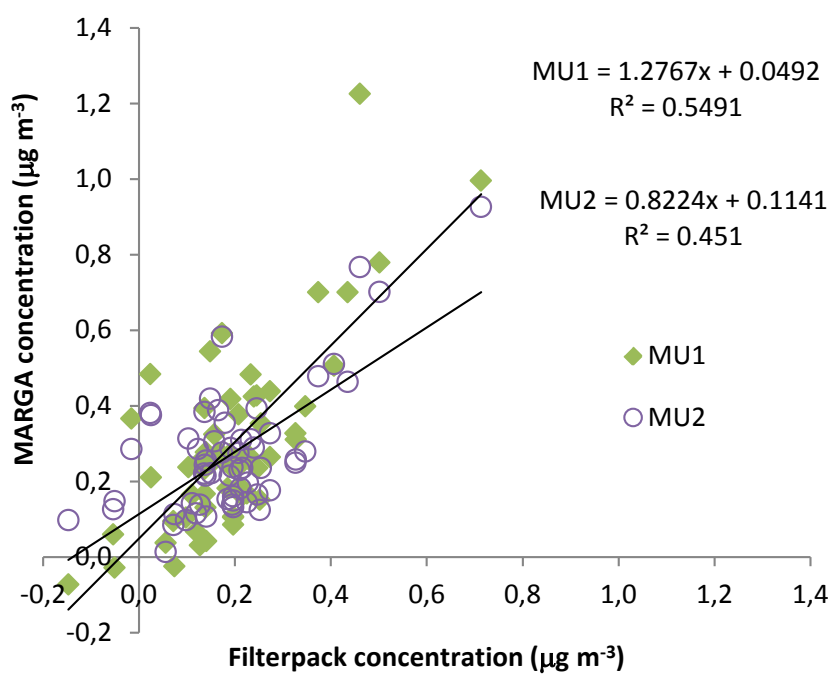

Figure 10. Regression analysis of estimated MARGA "fine" $\mathrm{NO}_{3}^{-}$ (total $\mathrm{NO}_{3}^{-}$minus $\mathrm{NaNO}_{3}$ ) concentrations against filter pack "fine", $\mathrm{NO}_{3}^{-}$(total $\mathrm{NO}_{3}^{-}$minus $\mathrm{NaNO}_{3}$ ) concentrations.

It is acknowledged that both the $\mathrm{Na}_{2} \mathrm{CO}_{3}$ denuder and the WRD are sensitive to measuring dinitrogen pentoxide $\left(\mathrm{N}_{2} \mathrm{O}_{5}\right)$ as $\mathrm{HNO}_{3}$ during the nighttime (Phillips et al., 2013). However, since both sampling techniques are likely influenced in a similar way, it will not affect the comparison between the $\mathrm{Na}_{2} \mathrm{CO}_{3}$ denuder and the WRD. This artifact may influence measured concentration levels. Phillips et al. (2013) reported that on average $\mathrm{N}_{2} \mathrm{O}_{5}$ contributed $17 \%$ of MARGA measured nighttime $\mathrm{HNO}_{3}$ at a sampling site near Frankfurt, Germany. The magnitude of $\mathrm{N}_{2} \mathrm{O}_{5}$ concentration varies in different geographic locations and is influenced by nitric oxide (NO) concentration, biogenic volatile organic compound (VOC) concentrations and air temperature (Phillips et al., 2013). In this study, the influence of $\mathrm{N}_{2} \mathrm{O}_{5}$ on measured $\mathrm{HNO}_{3}$ is likely to be small as $\mathrm{N}_{2} \mathrm{O}_{5}$ concentration levels are expected to be low due to high $\mathrm{NO}$ and biogenic VOC concentrations and warm air temperatures, which decrease $\mathrm{N}_{2} \mathrm{O}_{5}$ concentrations.

The MARGA performed moderately for $\mathrm{HNO}_{3}$. The MARPD between the MUs was $22.8 \%$, which met by a small margin the precision goal of $25 \%$. However, the MUs did not meet the accuracy slope goal, with MU1 having a slope of 0.73 and MU2 having a slope of 0.57 (Fig. 12). However, both MUs did meet the accuracy MARPD goal, with values of $21.2 \%$ for MU1 and $29.0 \%$ for MU2. As previously mentioned, it was hypothesized that $\mathrm{HNO}_{3}$ was adsorbed onto active sites in the tubing and inlet, and that factors that vary diurnally influenced this, thus causing the diurnal cycle of under and over measurement in comparison to the denuder. To investigate this phenomenon further, the denuder and MARGA concentrations were averaged over $24 \mathrm{~h}$. Figure 13 presents the $24 \mathrm{~h}$ averaged concentrations measured by the instruments during the ETV. By averaging over $24 \mathrm{~h}$, the effect of the diurnal cycle, and thus the adsorption, is partly accounted for. This results in an improvement in the similarity of the concentration trends for the MUs and the denuder. Using $24 \mathrm{~h}$ averages, the slope values for the MUs against the denuder also improved. The slope for MU1 improved to 0.90 (Fig. 14), passing the slope accuracy goal of 0.8. However, the slope for MU2, which was 0.69 (Fig. 14), did not improve enough to pass the accuracy goal. In addition, the accuracy MARPD also improved, with values of 11.2 and $17.1 \%$ for MU1 and MU2, respectively.

\subsection{5 $\mathrm{NH}_{4}^{+}$}

As mentioned in Sect. 3.1, the adjustment of $\mathrm{NH}_{4}^{+}$for the external standard analytical bias was more complicated than for other compounds and therefore warrants a detailed discussion. Presented in Fig. 15 are the $\mathrm{NH}_{4}^{+}$concentration trends during the ETV period after applying the same analytical bias adjustment method as for the previous compounds. $\mathrm{NH}_{4}^{+}$ concentrations were generally at their highest from 8 to 26 September(prior to rain event). When the rain event started on 26 September, there was then a rapid decrease in concentrations. During the rain event concentrations remained low, before slowly increasing towards the end of the ETV period. From 8 September until $\approx 25$ September, the MUs measured higher concentrations in comparison to the filter pack $(\approx 24 \%$ for MU1 and $\approx 31 \%$ for MU2). From $\approx 25$ September until 8 October, the filter pack and MU concentrations were more similar, with filter pack concentrations generally slightly higher than those of the MUs. Figure 16a presents the $\mathrm{NH}_{4}^{+}$concentration trend unadjusted for the external standard and Fig. 16b shows the corresponding concentration difference (Filter pack minus MUs) between the filter pack and the MUs. The unadjusted data in Fig. 16a show that before $\approx 25$ September, the MU and filter pack concentrations were very similar, and that after this date the filter pack concentrations were consistently higher than MU concentrations. This pattern is shown more clearly by examination of the concentration difference between the filter pack and the MUs (Fig. 16b). It can be observed that before 19:00 on 25 September, the concentration difference fluctuates between positive and negative, with there being no discernible pattern. From 19:00 on 25 September until the end of the ETV period, a different pattern emerges with the filter pack concentrations consistently higher than the MU concentrations.

A possible explanation for this change in pattern is related to the presence of bacteria in the MARGA system. Bacteria are aerosolized from almost all surfaces including soil, plants and water surfaces (Burrows et al., 2009a) and are therefore ubiquitous in the atmosphere (Despres et al., 2012; Burrows et al., 2009b; Jaenicke, 2005). It can therefore be assumed that the MARGA is routinely sampling bacteria.

The SJAC and WRD both represent pathways by which bacteria may be introduced to the liquid flow path of the 


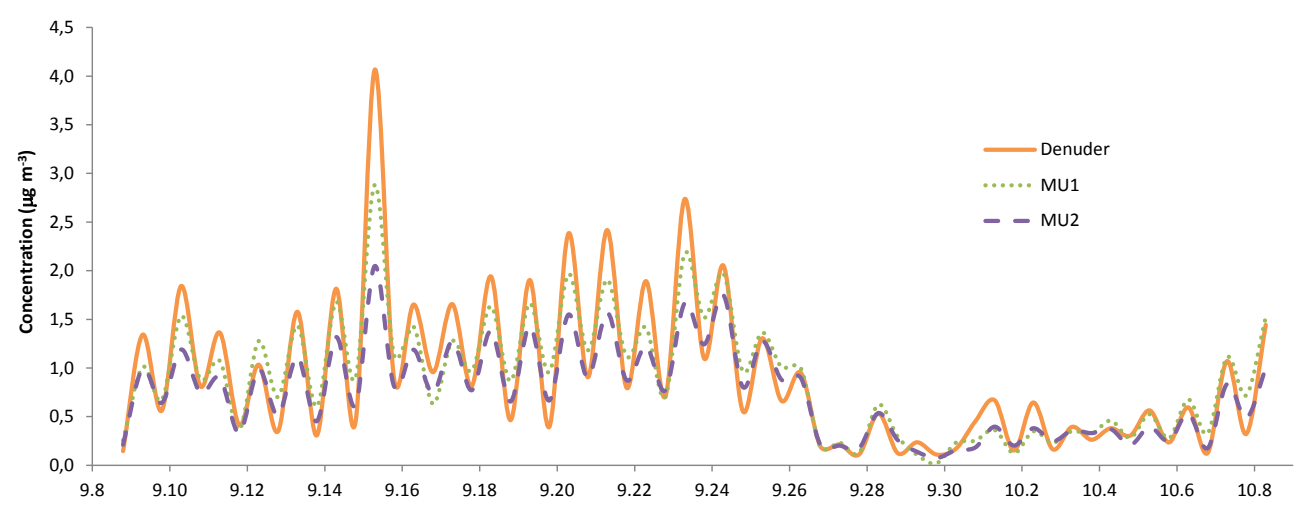

Figure 11. Denuder and $\mathrm{MU}$ measured $\mathrm{HNO}_{3}$ concentrations during the ETV period.

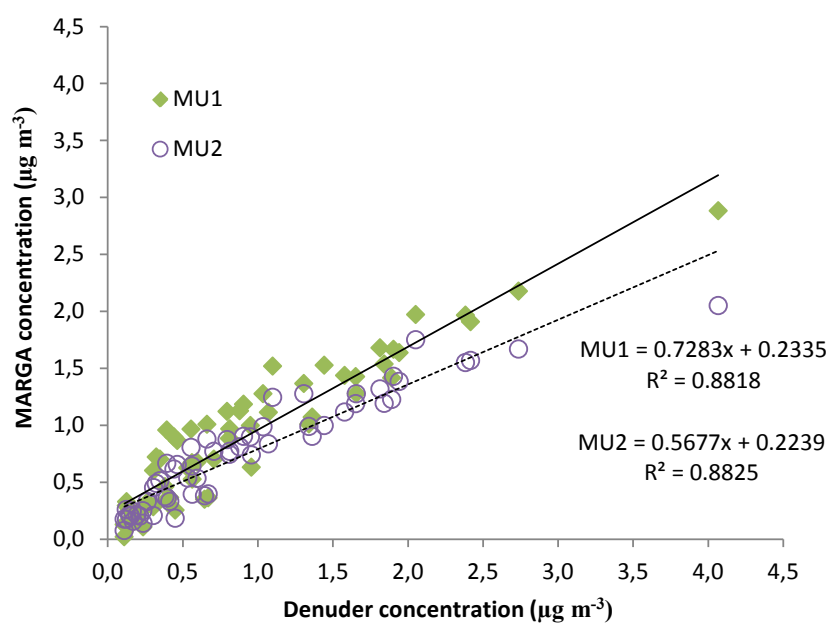

Figure 12. Regression analysis of MARGA $\mathrm{HNO}_{3}$ concentrations against denuder $\mathrm{HNO}_{3}$ concentrations.

MARGA. Though the SJAC steamer operates at $\approx 150^{\circ} \mathrm{C}$, the temperature of the liquid sample in the bottom of the SJAC $\left(\approx 35^{\circ} \mathrm{C}\right)$ and the sample airstream near the steamer outlet $\left(\approx 40{ }^{\circ} \mathrm{C}\right)$ are sufficiently cool for bacteria to survive. Deposition of large particles in the WRD is another potential source of bacteria. Thomas et al. (2009) characterized the performance of the GRAEGOR (gradient of aerosols and gases online registrator), which employs the same sampling collection system as the MARGA. They found that while sampling $\mathrm{PM}_{10}$, there was a $3.3 \%$ loss of the $\mathrm{Na}^{+}$ aerosol to the WRD due to the gravitational settling of particles. Because of the larger particle cutoff $(\approx 26 \mu \mathrm{m})$ used in the present study, the potential losses to the WRD are even greater.

Liquid samples from the WRD and the SJAC flow through a $1 \mu \mathrm{m}$ pore size Teflon filter prior to analysis by the IC system. Many bacteria are smaller than $1 \mu \mathrm{m}$, and may pass through the filter and accumulate on filters associated with the IC system. It can be concluded that bacterial contamination in the WRD sample stream or the SJAC sample stream would only affect that sample type. However, bacterial contamination in the IC system would affect both the SJAC and WRD samples. Therefore, bacterial contamination in both the SJAC and denuder sample streams or bacterial contamination in the IC system could explain potential $\mathrm{NH}_{4}^{+}$losses that would negatively bias $\mathrm{NH}_{4}^{+}$and $\mathrm{NH}_{3}$ air concentrations.

Microbiological processing of $\mathrm{NH}_{4}^{+}$, which has been put forth as an explanation for $\mathrm{NH}_{4}^{+}$loss in precipitation samples (Ramundo and Seastedt, 1990; Krupa, 2002), is a possible explanation for $\mathrm{NH}_{4}^{+}$underestimation. However, $\mathrm{NH}_{4}^{+}$ consumption by nitrifying bacteria would also have the effect of an increase in $\mathrm{NO}_{3}^{-}$, which was not observed. Thus our hypothesis is that the $\mathrm{NH}_{4}^{+}$is being incorporated into biomass (i.e., immobilized).

High concentrations of particulate $\mathrm{Na}^{+}$(Fig. 8) were observed between 21 and 25 September, with the highest peaks occurring on 21 and 25 September. As described in Sect. 3.4.3, the MUs measured higher concentrations of $\mathrm{Na}^{+}$ due to the sampling of coarse aerosol. It is hypothesized that these coarse aerosols contained bacteria and were introduced to the MARGA systems, contributing to the observed $\mathrm{NH}_{4}^{+}$loss from 25 September onwards. Our ongoing MARGA field sampling supports this explanation as similar $\mathrm{NH}_{4}^{+}$loss events, hereafter referred to as "bacterial consumption events", have continued to be observed. These bacterial consumption events are associated with marine air masses, which are indicated by the presence of the $\mathrm{Na}^{+}$aerosol, which is emitted by sea spray. Sea spray is also a source of bacteria (Blanchard and Syzdek, 1982). Bacteria and other microorganisms can have an atmospheric residence time on the order of days and weeks (Burrows et al., 2009a). This is because many microorganisms have defense mechanisms allowing them to survive the environmental stresses of air transport such as $\mathrm{UV}$ radiation and varying $\mathrm{pH}$ and moisture levels (Burrows et al., 2009a). Therefore a possible explanation is that the bacterial consumption events are caused by transported marine bacteria associated with coarse aerosols. It is not known whether the coarseness or the source of the aerosol (i.e., marine) or a combination of both are factors in 


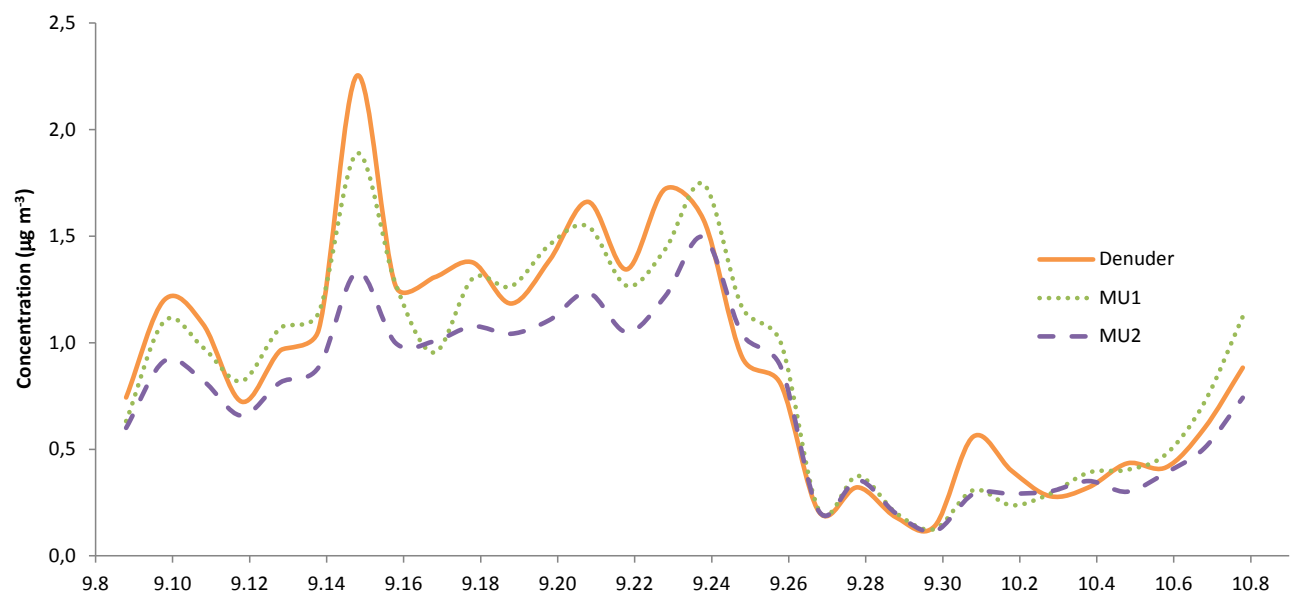

Figure 13. Denuder and MU measured $24 \mathrm{~h}$ average $\mathrm{HNO}_{3}$ concentrations during the ETV period.

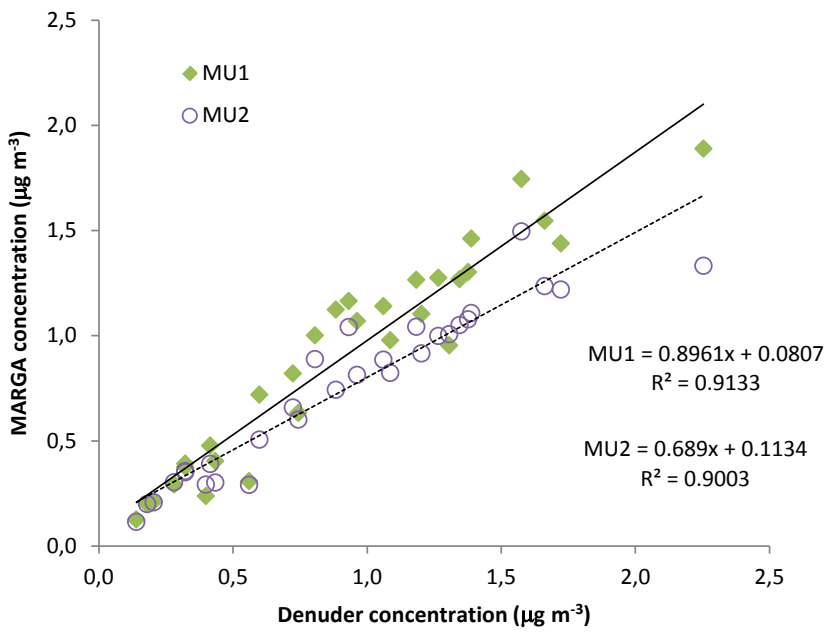

Figure 14. Regression analysis of $24 \mathrm{~h}$ average MARGA $\mathrm{HNO}_{3}$ concentrations against denuder $\mathrm{HNO}_{3}$ concentrations.

the bacterial consumption events. However, it should be considered that marine bacteria may be more adept at colonizing in the aqueous environment of the MARGA sampling system. Further evidence for associating the $\mathrm{NH}_{4}^{+}$losses with bacterial consumption is from our ongoing field sampling where the MARGA system has been rinsed using $0.1 \%$ peracetic acid as a disinfectant after a bacterial consumption event has occurred. This practice has to been found to stop the bacterial consumption of $\mathrm{NH}_{4}^{+}$. This has been confirmed by running external standards with a known $\mathrm{NH}_{4}^{+}$concentration before and after the rinse. Due to the uncertainty associated with the cause of the bacterial consumption events, the geographic areas that could be affected by bacterial consumption events are unknown.

A previous study by Wolff et al. (2010), which made deposition measurements using the GRAEGOR, supports the hypothesis of bacterial consumption of $\mathrm{NH}_{4}^{+}$. They concluded that low $\mathrm{NH}_{4}^{+}$concentrations measured by one of their sample boxes was the result of bacterial consumption of $\mathrm{NH}_{4}^{+}$. Wolff et al. (2010) hypothesized that the bacteria survived on the walls of the SJAC. However, it should be noted that unlike this study, the absorption solution used in the Wolff et al. (2010) study did not contain hydrogen peroxide.

As previously discussed, an external standard was run after the ETV period. Results showed the analytical bias for $\mathrm{NH}_{4}^{+}$to be $-14.5 \%$ for MU1 and $-21.1 \%$ for MU2. It is assumed that the negative bias is related to microbiological processes; therefore a correction method is needed to compensate for this. Complex factors regarding microbial populations make this a difficult task. For instance, the dynamics of the microbial population regulate the amount of $\mathrm{NH}_{4}^{+}$ that can be consumed. In this case, we assume for simplicity that the population size is limited by carbon or phosphorous, rather than nitrogen, and that the loss of $\mathrm{NH}_{4}^{+}$is therefore not proportional to the $\mathrm{NH}_{4}^{+}$concentration. Given this, we assume that it is more appropriate to correct for the external standard by applying an offset (difference between observed and expected concentration (see the Supplement for external standard results)) instead of a percentage. This gives offset values of 0.16 and $0.23 \mu \mathrm{g} \mathrm{m}^{-3}$ for MU1 and MU2, respectively. The concentration difference between the MUs and filter pack (Fig. 16b) suggests that the data from 19:00 on 25 September onwards are affected by the bacterial consumption; therefore the offset adjustment was applied to this portion of the data. Furthermore, in ongoing field sampling, two external standards have been run after a bacteria consumption event and have confirmed that an offset correction for $\mathrm{NH}_{4}^{+}$is appropriate.

To support the offset adjustment of these data, ammonium sulfate ratios $\left(\mathrm{NH}_{4}^{+} / \mathrm{SO}_{4}^{2-}\right)$ were investigated. The molar ratio of $\mathrm{NH}_{4}^{+} / \mathrm{SO}_{4}^{2-}$ in North Carolina is typically between 1.25 and 2.0 (Walker et al., 2006; Baek and Aneja, 2004; McCulloch et al., 1998), with a value of 2.0 indicating the 


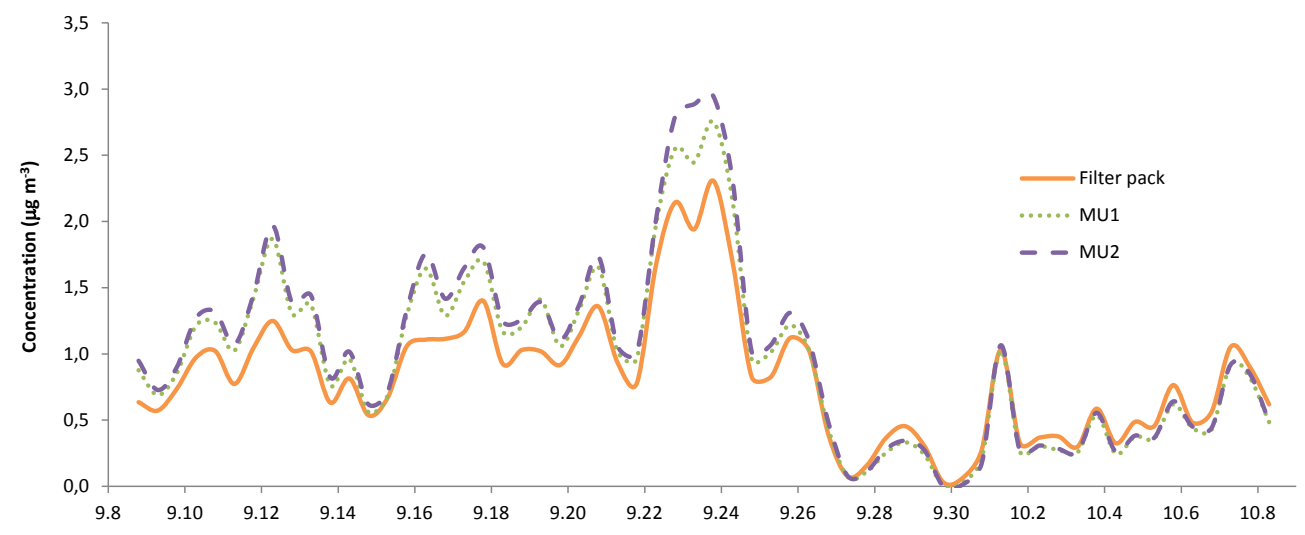

Figure 15. Filter pack and MU measured $\mathrm{NH}_{4}^{+}$concentrations (after adjusting for the external standard as a percentage) during the ETV period.
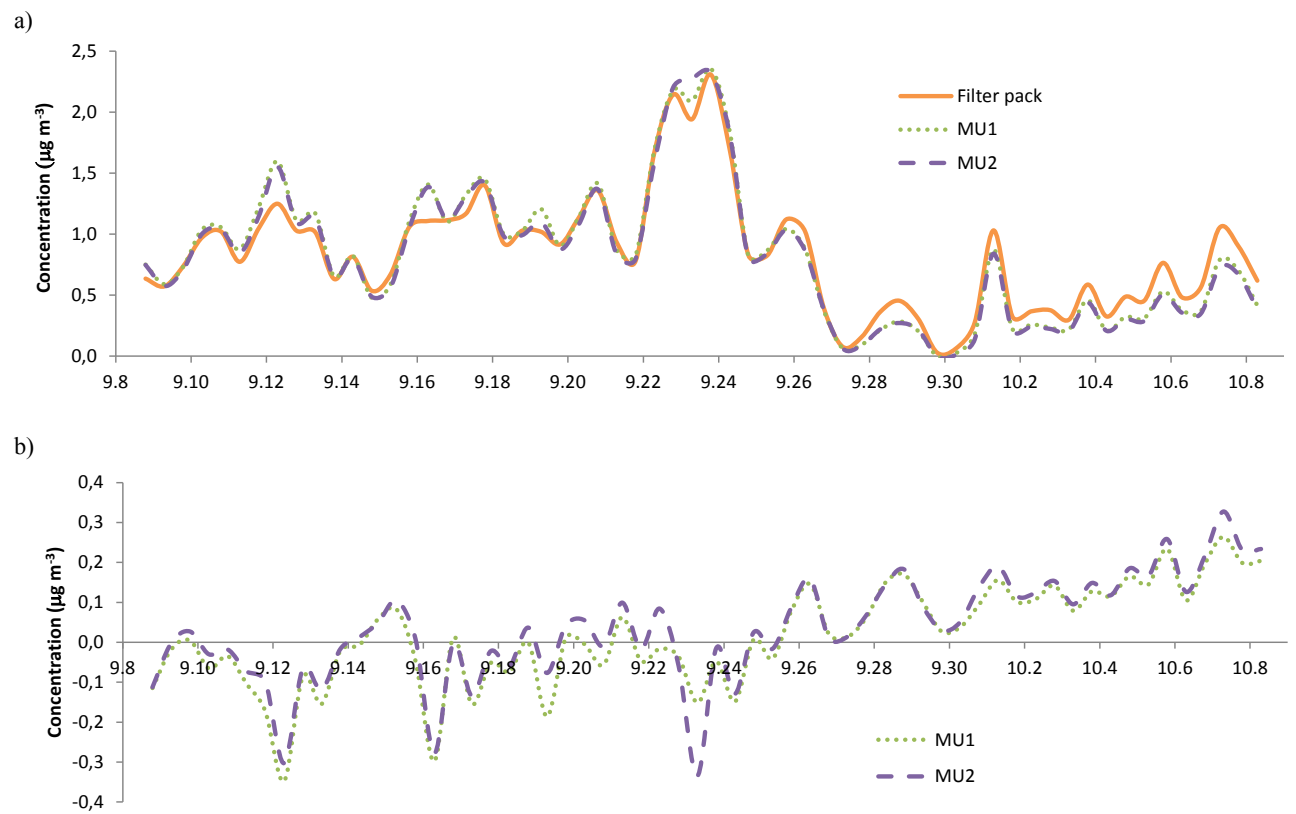

Figure 16. (a) $\mathrm{NH}_{4}^{+}$concentration trends for the MUs (unadjusted for the external standard) and the filter pack during the ETV period. (b) Concentration difference (filter pack minus MUs) between the filter pack and the $\mathrm{MUs}_{4}^{+}$concentrations (unadjusted for the external standard).

complete neutralization of $\mathrm{SO}_{4}^{2-}$. Using this range as a guide, the molar ratio of $\mathrm{NH}_{4}^{+} / \mathrm{SO}_{4}^{-2}$ can be used to assess if an offset adjustment is appropriate for the post-25 September period. To calculate this ratio, the amount of $\mathrm{NH}_{4}^{+}$associated with $\mathrm{SO}_{4}^{2-}$ has to be determined. This involves estimating the amount of $\mathrm{NH}_{4} \mathrm{NO}_{3}$. For $\mathrm{NH}_{4} \mathrm{Cl}$, it was assumed that concentrations were negligible. This is supported by the filter pack results (cutoff $=2.5 \mu \mathrm{m}$ ) for the ETV period, in which all of the $\mathrm{Cl}^{-}$concentrations collected by a Teflon filter were below the detection limit of $\approx 0.074 \mu \mathrm{g} \mathrm{m}^{-3}$. To estimate $\mathrm{NH}_{4} \mathrm{NO}_{3}$, the $\mathrm{NO}_{3}^{-}$molar equivalent of the measured $\mathrm{Na}^{+}$was subtracted from the total $\mathrm{NO}_{3}^{-}$. This calculation assumes that the cation component of the $\mathrm{NO}_{3}^{-}$aerosol is either
$\mathrm{NH}_{4}^{+}$or $\mathrm{Na}^{+}$. From examination of the concentrations of the cation component of the coarse $\mathrm{NO}_{3}^{-}$aerosol in Fig. 8, it can be determined that there is only a small amount of error in this assumption. The $\mathrm{NO}_{3}^{-}$(adjusted for $\mathrm{Na}^{+}$concentrations) was then subtracted from $\mathrm{NH}_{4}^{+}$, leaving the $\mathrm{NH}_{4}^{+}$associated with $\mathrm{SO}_{4}^{2-}$. The molar ratio of $\mathrm{NH}_{4}^{+} / \mathrm{SO}_{4}^{2-}$ was calculated for both the MUs and the filter pack. For the MUs, the molar ratio of $\mathrm{NH}_{4}^{+} / \mathrm{SO}_{4}^{2-}$ was calculated with $\mathrm{NH}_{4}^{+}$data being adjusted and unadjusted for the offset. The $\mathrm{NH}_{4}^{+} / \mathrm{SO}_{4}^{2-}$ ratios for the ETV period are shown in Fig. 17. From 8 until 24 September, the filter pack $\mathrm{NH}_{4}^{+} / \mathrm{SO}_{4}^{2-}$ ratio is almost completely between 1.5 and 2.0. Similarly, during this period, the corresponding $\mathrm{NH}_{4}^{+} / \mathrm{SO}_{4}^{2-}$ ratio for the unadjusted $\mathrm{MU}$ 


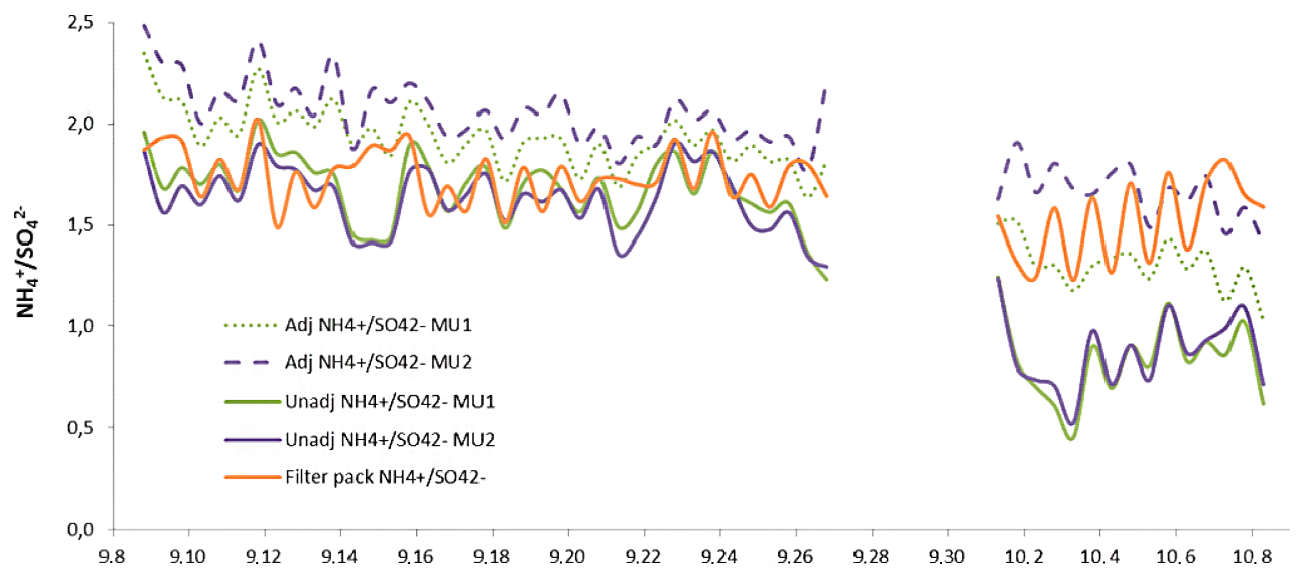

Figure 17. Ammonium sulfate ratios $\left(\mathrm{NH}_{4}^{+} / \mathrm{SO}_{4}^{2-}\right.$ ) calculated for the filter pack and the MUs adjusted (Adj) and unadjusted (Unadj) for the offset.

$\mathrm{NH}_{4}^{+}$data is also almost completely between 1.5 and 2.0 and follows quite closely the trend of the filter pack. Therefore both ratios are in the normal range of 1.25 to 2.0. However, the $\mathrm{NH}_{4}^{+} / \mathrm{SO}_{4}^{2-}$ ratio for the $\mathrm{NH}_{4}^{+}$data that have been offset adjusted for the external standard is often above 2.0 during the 8 to 24 September period. On 25 and 26 September there is a decrease in the ratios for both the adjusted and unadjusted $\mathrm{NH}_{4}^{+} / \mathrm{SO}_{4}^{2-}$ ratios. However, both ratios are in the typical range of 1.25 to 2.0 ; therefore there is no clear evidence for which one is more accurate. In the period from 27 to 30 September, the ratios are not presented as these values were invalid and uninterpretable due to the near-zero aerosol concentrations during this period. From 1 to 8 October, the filter pack $\mathrm{NH}_{4}^{+} / \mathrm{SO}_{4}^{2-}$ ratio was lower than before the precipitation event, with ratios varying from $\approx 1.25$ to 1.85. In this period adjusted MU ratios are similar to those of the filter pack, ranging from $\approx 1.0$ to 1.9 . It can be observed that the adjusted MU2 ratio is higher than the adjusted MU1 ratio. From 1 to 8 October the unadjusted MU ratios are much lower than both the filter pack and the adjusted MU ratios, with the majority of the ratio during this period below 1.0 , and thus outside the normal range of 1.25 to 2.0. Overall, it can be concluded that the $\mathrm{NH}_{4}^{+} / \mathrm{SO}_{4}^{2-}$ ratio supports not adjusting the data before 24 September. In the 25 to 26 September period, there is no clear evidence to support either the adjusted or the unadjusted ratios, and the data in the 27 to 30 September period are uninterpretable due to near-zero aerosol concentrations. However, the $\mathrm{NH}_{4}^{+} / \mathrm{SO}_{4}^{2-}$ ratios do support an offset adjustment of the data from 1 October onwards.

As a result of the analysis of the concentration difference between the filter pack and the MUs and the $\mathrm{NH}_{4}^{+} / \mathrm{SO}_{4}^{2-}$ ratios, the $\mathrm{NH}_{4}^{+}$concentrations were adjusted as an offset from 25 September at 19:00. This time was selected as the start of the bacterial consumption event because it is the beginning of the change in concentration difference between the filter pack and the MUs (Fig. 16b). It is acknowledged that there are some uncertainties associated with this adjustment. Firstly, by the use of the offset, it is assumed that the bacterial consumption of $\mathrm{NH}_{4}^{+}$is constant. Additionally, this approach assumes negligible analytical bias.

The MU concentration trends after being adjusted for an offset from 19:00 on 25 September onwards are provided in Fig. 18. Observation of the post-25 September period shows that the offset adjustment results in the MU concentrations being very similar to the filter pack. Noticeably, the last $12 \mathrm{~h}$ average shows very small differences in concentrations, 0.58 for MU1 and 0.63 for MU2, in comparison to 0.62 for the denuder. This supports the validity of applying the offset adjustment. The overall average concentrations for the MUs were very similar with values of $0.89 \mu \mathrm{g} \mathrm{m}^{-3} \pm 0.50$ and $0.90 \mu \mathrm{g} \mathrm{m}^{-3} \pm 0.48$ for MU1 and MU2, respectively. The filter pack average concentration was slightly lower with a value of $0.83 \mu \mathrm{g} \mathrm{m}^{-3} \pm 0.48$.

The MARGA met all accuracy and precision goals for $\mathrm{NH}_{4}^{+}$. The precision between the MUs was excellent, with a MARPD of $5.3 \%$. The accuracy for $\mathrm{NH}_{4}^{+}$was also excellent, as the accuracy MARPD values for MU1 and MU2 were $6.7 \%$ and $8.6 \%$, respectively. The slope values from the linear regression analysis were 1.02 for MU1 and 0.97 for MU2 (Fig. 19). The excellent performance of the MARGA in measuring $\mathrm{NH}_{4}^{+}$is supported by the study by Makkonen et al. (2012), in which measured MARGA $\mathrm{NH}_{4}^{+}$concentrations were compared to $\mathrm{NH}_{4}^{+}$concentrations from a Teflon filter using linear regression, resulting in a slope value of 0.91 for $\mathrm{NH}_{4}^{+}$.

\subsection{6 $\quad \mathrm{NH}_{3}$}

The $\mathrm{NH}_{3}$ concentration trends during the ETV test are presented in Fig. 20a. Similarly to other compounds, concentrations were generally highest before the rain event on 26 September. Prior to the rain event, the $\mathrm{NH}_{3}$ concentrations 


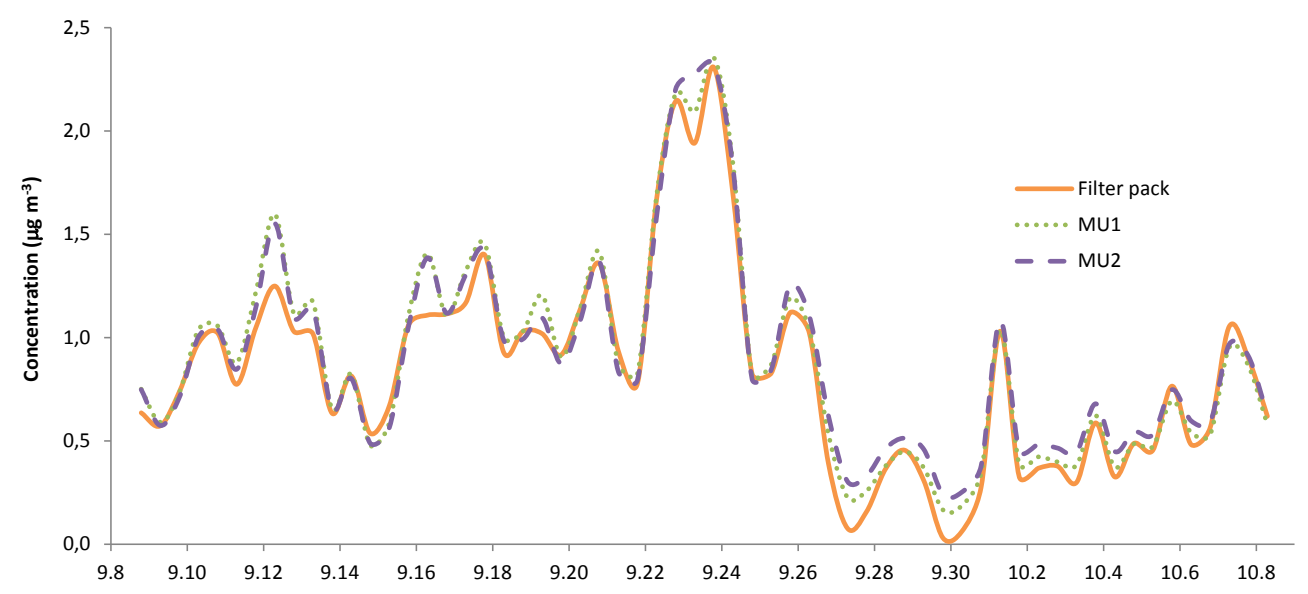

Figure 18. Filter pack and MU measured $\mathrm{NH}_{4}^{+}$concentrations (after adjusting for the external standard as an offset after 19:00 on 25 September) during the ETV period.

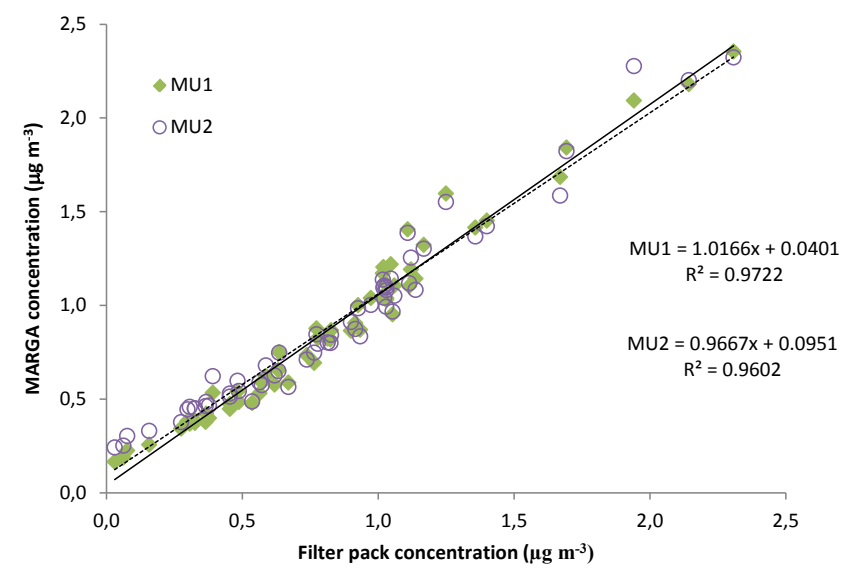

Figure 19. Regression analysis of MARGA $\mathrm{NH}_{4}^{+}$concentrations against filter pack $\mathrm{NH}_{4}^{+}$concentrations.

fluctuated with concentrations generally higher during the day and lower at night. These daytime peaks may be due to the temperature dependence of the $\mathrm{NH}_{3}$ compensation point of the vegetation and soil surrounding the site (Massad et al., 2010). During the rain event, concentrations decreased. After the rain event, there were a couple of concentration peaks (on 30 September and 7 October), but generally concentrations stayed low. It should be noted that the concentrations presented in Fig. 20a are unadjusted for the external standard analytical bias, due to the potential for bacterial consumption, which will be discussed in the following paragraph.

As discussed in Sect. 3.4.5, the MARGA is susceptible to the deposition of coarse aerosols and thus bacterial cells, leading to the potential development of bacterial colonies in the MARGA, resulting in the possible loss of $\mathrm{NH}_{3}$ as well as $\mathrm{NH}_{4}^{+}$. Therefore, before adjusting the concentration data for the external standard analytical bias, the unadjusted MU and filter pack concentration trends were examined (Fig. 20a) in combination with the concentration difference between the filter pack and the MUs (Fig. 20b) to identify any unexpected concentration trends, which would indicate that $\mathrm{NH}_{3}$ was affected by bacterial consumption.

The evidence of bacterial consumption for $\mathrm{NH}_{3}$ is not as clear as it is for $\mathrm{NH}_{4}^{+}$. However, it can be observed that there is a change in the concentration difference values around 23 September (see Fig. 20b). Before 23 September, the denuder concentration was generally slightly higher than the MUs concentrations. However, there were variations in the concentration difference, with MU2 occasionally having a larger concentration than the denuder. Starting on 23 September, the concentration difference increased. This increased concentration difference was fairly constant for a few days, but after $\approx 26$ September the concentration difference decreased. Thereafter the concentration difference fluctuated with large concentration difference peaks on 30 September and 7 October; however, the denuder concentration was never greater than the MU concentrations, unlike in the pre-23 September period.

It is proposed that the bacterial consumption event for $\mathrm{NH}_{3}$ started at 19:00 on 23 September. As discussed, ongoing research experience indicates that bacterial consumption events are triggered by marine air masses, which often contain coarse $\mathrm{Na}^{+}$aerosols. As discussed, there were high $\mathrm{Na}^{+}$ concentrations on 21 and 22 September (Fig. 8). The offset adjustments for $\mathrm{NH}_{3}\left(0.23 \mu \mathrm{g} \mathrm{m}^{-3}\right.$ for MU1 and $0.25 \mu \mathrm{g} \mathrm{m}^{-3}$ for MU2) are larger than the $\mathrm{NH}_{4}^{+}$offsets $\left(0.16 \mu \mathrm{g} \mathrm{m}^{-3}\right.$ for MU1 and $0.23 \mu \mathrm{g} \mathrm{m}^{-3}$ for MU2). These differences and the occurrence of denuder $\mathrm{NH}_{4}^{+}$losses before the SJAC $\mathrm{NH}_{4}^{+}$ losses (25 September) may indicate that the denuder is more susceptible to bacterial contamination than the SJAC. It is acknowledged that the effects of the bacterial consumption event are not as clear for $\mathrm{NH}_{3}$ as they are for $\mathrm{NH}_{4}^{+}$. Factors that may be hindering the observation of the bacterial consumption event include possible tubing and inlet 
a)

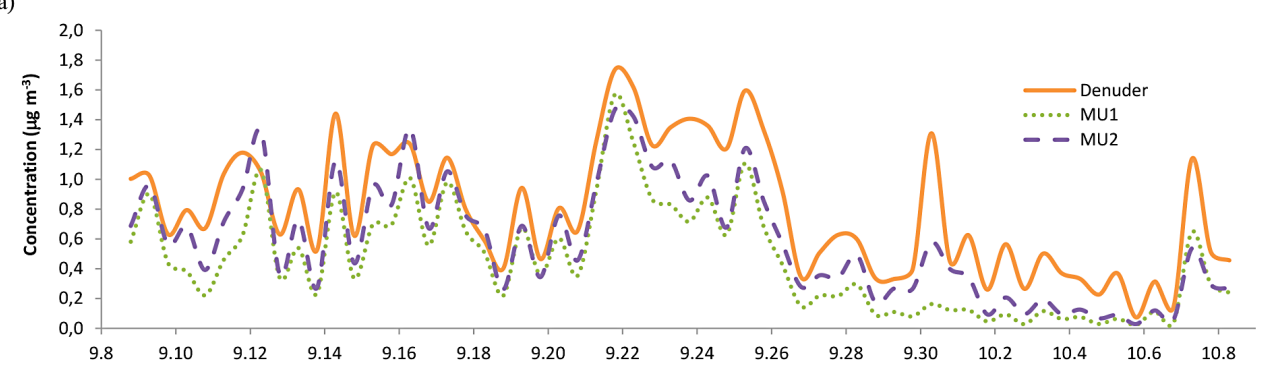

b)

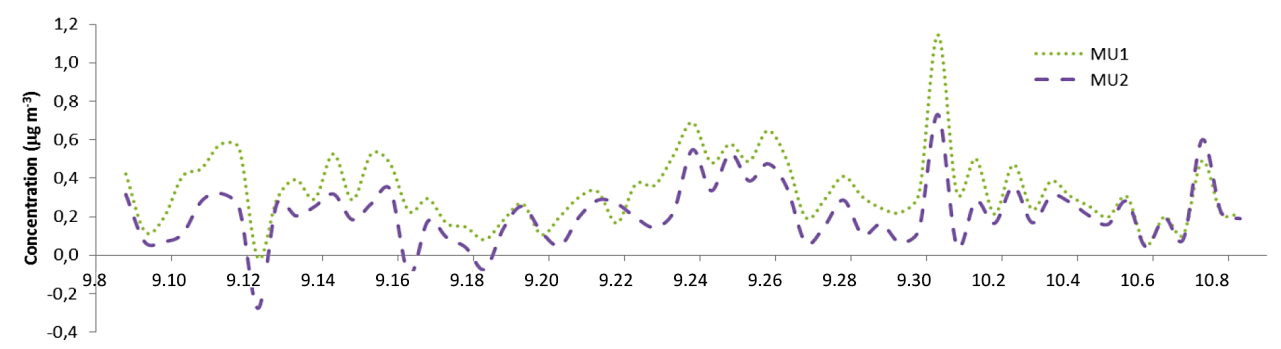

Figure 20. (a) Denuder and MU measured $\mathrm{NH}_{3}$ concentrations (unadjusted for the external standard) during the ETV period. (b) Concentration difference (denuder minus MUs) between the denuder and $\mathrm{MU} \mathrm{NH}_{3}$ concentrations (unadjusted for the external standard).

adsorption of $\mathrm{NH}_{3}$ and a high variable $\mathrm{NH}_{3}$ denuder blank (see Sect. 3.1).

The MU concentration trends after adjusting the response to the external standard as an offset from 19:00 on 23 September onwards are presented in Fig. 21. Observation of the post-23 September period indicates that the denuder and the MUs concentration trends are now closer. Overall though, the denuder still generally has higher concentrations in this period. The largest concentration difference between the denuder and MUs is for the 30 September and 7 October peaks. Noticeably, the last $12 \mathrm{~h}$ average shows a small difference in concentrations, 0.48 for MU1, and 0.53 for MU2, in comparison to 0.46 for the denuder. This supports the validity of applying an offset adjustment.

The MARGA performed moderately well for $\mathrm{NH}_{3}$. The MARPD between the MUs was $22.8 \%$, which met the precision goal of $25 \%$. The accuracy results were mixed. The accuracy MARPD values were good, with a MARPD of $27.0 \%$ for MU1 and $22.0 \%$ for MU2. However, the $\mathrm{NH}_{3}$ slope values for the linear regression were not as good, with values of 0.65 for MU1 and 0.72 for MU2 (Fig. 22), which are below the minimum slope goal of 0.8 . Similarly to $\mathrm{HNO}_{3}, \mathrm{NH}_{3}$ is a "sticky" gas; therefore it is thought that the difference in measured concentrations is likely the result of the adsorption of $\mathrm{NH}_{3}$ onto active sites on the MUs inlet and tubing. In addition, there was a variable $\mathrm{NH}_{3}$ denuder blank, which may have influenced the agreement between the denuder and the MUs. It is also possible that there was some inaccuracy associated with the external standard offset adjustment, as the adjustment does not take into account any analytical bias.

\subsection{Summary of MARGA evaluation}

A summary table of the performance of the MARGA in regards to the precision and accuracy goals is presented in $\mathrm{Ta}-$ ble 2. It should be noted that $\mathrm{NO}_{3}^{-}$is not included in the summary table. This is due to the different sampling efficiency of coarse $\mathrm{NO}_{3}^{-}$by the instruments. Results from the adjustment of the data for the coarse $\mathrm{NO}_{3}^{-}$fraction show that the MARGA would have had good agreement with the filter pack if they were sampling the same particle size. However, uncertainty in the correction for coarse $\mathrm{NO}_{3}^{-}$precludes a quantitative assessment of MARGA accuracy and precision. The ability of the MARGA to measure $\mathrm{NO}_{3}^{-}$accurately is supported by the findings of the Makkonen et al. (2012) study.

The MARGA performed extremely well in comparison to the denuder/filter pack for $\mathrm{SO}_{2}, \mathrm{SO}_{4}^{2-}$, and $\mathrm{NH}_{4}^{+}$, with all three compounds passing all their accuracy and precision goals by a significant margin. The MARGA performed moderately well in comparison to the denuder/filter pack for $\mathrm{HNO}_{3} . \mathrm{HNO}_{3}$ passed the precision goal and the accuracy MARPD goal. However, both slope values were below the goal of 0.8 . The performance of the MARGA in measuring $\mathrm{HNO}_{3}$ was likely influenced by the adsorption of $\mathrm{HNO}_{3}$ onto the sampling tubing and inlet. The effect of adsorption on measured MARGA concentrations was partly quantified by averaging the data over $24 \mathrm{~h}$. By averaging over $24 \mathrm{~h}$, the performance of the MARGA for $\mathrm{HNO}_{3}$ improved in the accuracy tests. This resulted in MU1 passing the slope accuracy goal. However, the slope value for MU2 (0.69) did not pass the goal. The MARGA also performed moderately for 


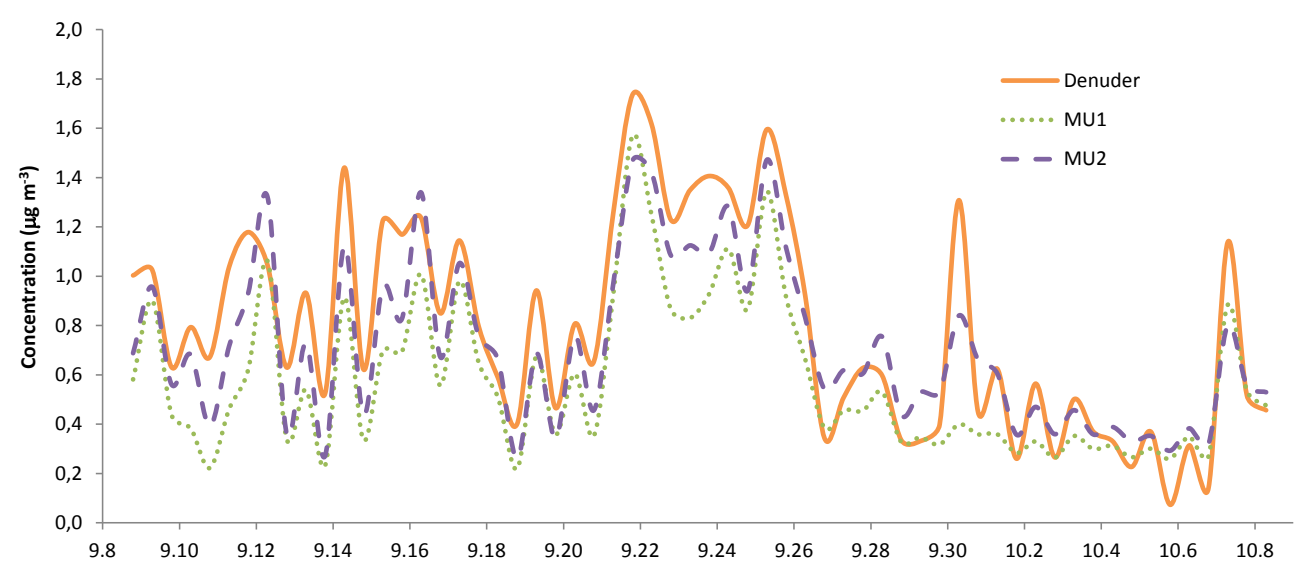

Figure 21. Denuder and MU measured $\mathrm{NH}_{3}$ concentrations (after adjusting for the external standard as an offset from 19:00 on 23 September onwards) during the ETV period.

Table 2. Summary of the performance of the MARGA in achieving accuracy and precision goals. Bolded values indicate the goal was passed.

\begin{tabular}{|c|c|c|c|c|c|}
\hline & \multirow{3}{*}{$\begin{array}{l}\text { Precision } \\
\text { MARPD }(\%)^{\mathrm{a}}\end{array}$} & \multicolumn{4}{|c|}{ Accuracy } \\
\hline & & \multicolumn{2}{|l|}{ MU1 } & \multicolumn{2}{|l|}{ MU2 } \\
\hline & & $\operatorname{MARPD}^{\mathrm{b}}(\%)$ & Slope $e^{c}$ & MARPD (\%) & Slope \\
\hline $\mathrm{SO}_{2}$ & 11.5 & 20.3 & 1.11 & 10.9 & 1.05 \\
\hline $\mathrm{SO}_{4}^{2-}$ & 3.2 & 12.1 & 0.97 & 8.3 & 0.98 \\
\hline $\mathrm{HNO}_{3}$ & 22.7 & 21.2 & 0.73 & 29.0 & 0.57 \\
\hline $\mathrm{HNO}_{3}-24 \mathrm{~h}^{\mathrm{d}}$ & - & 11.0 & 0.90 & 17.1 & 0.69 \\
\hline $\mathrm{NH}_{4}^{+}$ & 5.3 & 6.7 & 1.02 & 8.6 & 0.97 \\
\hline $\mathrm{NH}_{3}^{4}$ & 22.8 & 27.0 & 0.65 & 22.0 & 0.72 \\
\hline
\end{tabular}

a The precision goal for the MARPD was to be $\leq 25 \%$.

b The accuracy goal for the MARPD was to be $\leq 40 \%$.

$\mathrm{c}$ The accuracy goal for the slope was to be between 0.8 and 1.2.

$\mathrm{d}$ Accuracy determined using $24 \mathrm{~h}$ averaged data.

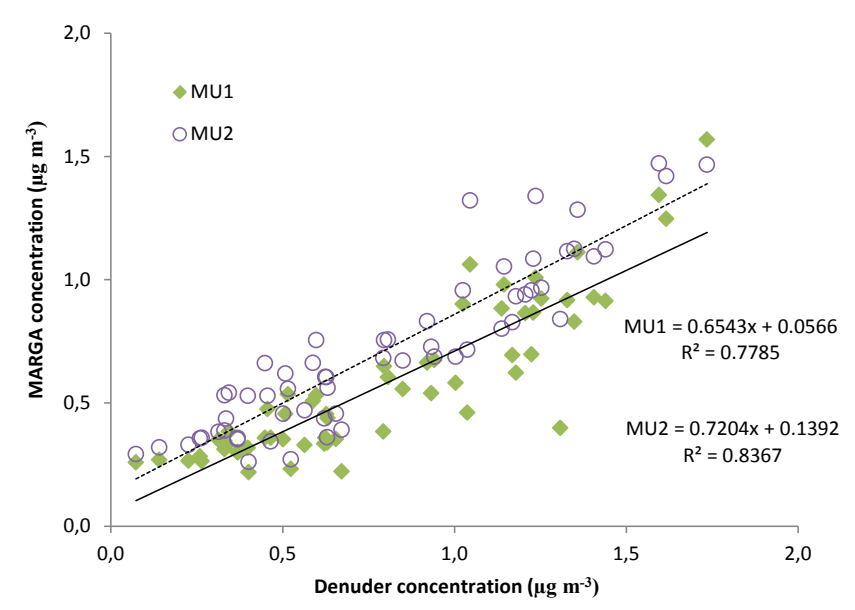

Figure 22. Regression analysis of MARGA $\mathrm{NH}_{3}$ concentrations against denuder $\mathrm{NH}_{3}$ concentrations.
$\mathrm{NH}_{3}$. Both MU1 and MU2 passed the precision and accuracy MARPD goals; however they did not pass the slope accuracy goal, with slope values of 0.65 for MU1 and 0.72 for MU2. Similarly to $\mathrm{HNO}_{3}$, it is thought that adsorption by the sample tubing and inlet may have influenced the measured $\mathrm{NH}_{3}$ concentrations. Other factors that may have influenced the agreement between denuder and MU measured concentrations include a variable $\mathrm{NH}_{3}$ denuder blank and the accuracy of the external standard offset adjustment.

\section{Conclusions and recommendations}

In comparison to the denuder/filter pack, the MARGA performed very well in measuring concentrations of $\mathrm{SO}_{2}, \mathrm{SO}_{4}^{2-}$, and $\mathrm{NH}_{4}^{+}$, with all three species passing their precision and accuracy goals by a large margin. The performance of the MARGA in measuring $\mathrm{NO}_{3}^{-}$could not be evaluated as the MARGA and filter pack had different particle cutoffs, which influenced the sampling of coarse $\mathrm{NO}_{3}^{-}$. The MARGA performed moderately well in measuring $\mathrm{HNO}_{3}$ 
and $\mathrm{NH}_{3}$ in comparison to the denuder. In this study, the sample airstream was drawn through a $\approx 4$ m length of $0.5^{\prime \prime}$ outer-diameter (O.D.) polyethylene tubing. To improve the performance of the MARGA in measuring $\mathrm{HNO}_{3}$ and $\mathrm{NH}_{3}$, it is recommended that a more inert tubing material, such as perfluoroalkoxy (PFA) Teflon, be used (Neuman et al., 1999), and that the length of tubing be as short as possible. Ideally, the length of sample tubing could be minimized by locating the sample box at the point of atmospheric sampling. To improve the performance of the inlet for $\mathrm{HNO}_{3}$ and $\mathrm{NH}_{3}$, it is recommended that the inlet be Teflon coated.

To improve the accuracy of MARGA $\mathrm{NH}_{3}$ and $\mathrm{NH}_{4}^{+}$measurements, it is recommended that when a bacterial consumption event occurs (identified by a sudden change in the $\mathrm{NH}_{4}^{+} / \mathrm{SO}_{4}^{2-}$ ratio), that at least two external standards be analyzed with different concentrations to quantify the slope and offset of $\mathrm{NH}_{3}$ and $\mathrm{NH}_{4}^{+}$adjustments. After running the external standards, it is recommended that the bacterial contamination be eliminated by "disinfecting" the system with peracetic acid, which has been observed to successfully clean the liquid flow path during subsequent field experiments.

It can be concluded that $\mathrm{SO}_{4}^{2-}, \mathrm{SO}_{2}, \mathrm{NO}_{3}^{-}, \mathrm{HNO}_{3}, \mathrm{NH}_{4}^{+}$, and $\mathrm{NH}_{3}$ concentrations can be measured with acceptable accuracy and precision when the MARGA is operated in conjunction with the recommendations outlined above. Ongoing MARGA projects are investigating the periodic loss of $\mathrm{NH}_{4}^{+}$ in more detail and the feasibility of gradient flux measurements as a potential application for the MARGA. This will also offer a further opportunity to evaluate the MARGA over a wider range of concentrations, which was a limitation in the present study.

\section{The Supplement related to this article is available online at doi:10.5194/acp-14-5639-2014-supplement.}

Acknowledgements. We would like to thank Solomon Ricks, Keith Kronmiller and Nealson Watkins of EPA-OAQPS for providing hourly $\mathrm{SO}_{2}$ data. We would also like to thank Jerry van Bronckhorst of Metrohm Applikon for his assistance with the setup of the MARGA for the ETV. We acknowledge Jon Bowser's (TRC Environmental) significant contributions to the development and testing of the MARGA. This manuscript has been reviewed in accordance with US EPA policy and approved for publication. Mention of trade names or commercial products does not constitute endorsement or recommendation of use by the Agency.

Edited by: C. K. Chan

\section{References}

Adams, P. J., Seinfeld, J. H., and Koch, D.: Global concentrations of tropospheric sulfate, nitrate, and ammonium aerosol simulated in a general circulation model, J. Geophys. Res., 104, 1379113823, 1999.

Baek, B. H. and Aneja, V. P.: Measurement and analysis of the relationship between ammonia, acid gases, and fine particles in eastern North Carolina, J. Air Waste Manage. Assoc., 54, 623-633, 2004.

Blanchard, D. and Syzdek, L.: Water-to-air transfer and enrichment of bacteria in drops from bursting bubbles, Appl. Environ. Microbiol., 43, 1001-1005, 1982.

Burrows, S. M., Butler, T., Jöckel, P., Tost, H., Kerkweg, A., Pöschl, U. and Lawrence, M. G.: Bacteria in the global atmosphere - Part 2: Modeling of emissions and transport between different ecosystems, Atmos. Chem. Phys., 9, 9281-9297, doi:10.5194/acp-99281-2009, 2009a.

Burrows, S. M., Elbert, W., Lawrence, M. G., and Pöschl, U.: Bacteria in the global atmosphere - Part 1: Review and synthesis of literature data for different ecosystems, Atmos. Chem. Phys., 9, 9263-9280, doi:10.5194/acp-9-9263-2009, 2009b.

Despres, V. R., Huffman, J. A., Burrows, S. M., Hoose, C., Safatov, A. S., Buryak, G., Fröhlich-Nowoisky, J., Elbert, W., Andreae, M. O., Pöschl, U., and Jaenicke, R.: Primary biological aerosol particles in the atmosphere: a review, Tellus. B., 64, 15598, doi:10.3402/tellusb.v64io.15598, 2012.

Galloway, J. N.: Acid deposition: Perspectives in time and space, Water, Air and Soil Pollut., 85, 15-24, 1995.

Galloway, J. N., Aber, J. D., Erisman, J. W., Seitzinger, S. P., Howarth, R. B., Cowling, E. B., and Cosby, B. J.: The nitrogen cascade, Bioscience, 53, 341-356, 2003.

Gibson, E. R., Hudson, P. K., and Grassian, V. H.: Physicochemical properties of nitrate aerosols: Implications for the atmosphere, J. Phys. Chem. A, 110, 11785-11799, 2006.

Godri, K. J., Evans, G. J., Slowik, J., Knox, A., Abbatt, J., Brook, J., Dann, T., and Dabek-Zlotorzynska, E.: Evaluation and application of a semi-continuous chemical characterization system for water soluble inorganic PM2.5 and associated precursor gases, Atmos. Meas. Tech., 2, 65-80, doi:10.5194/amt-2-652009, 2009.

Jaenicke, R.: Abundance of cellular material and proteins in the atmosphere, Science, 308, 73, 2005.

Keuken, M. P., Schoonebeek, C. A. M., van Wensveen-Louter, A., and Slanina, J.: Simultaneous sampling of $\mathrm{NH}_{3}, \mathrm{HNO}_{3}, \mathrm{HCl}$, $\mathrm{SO}_{2}$ and $\mathrm{H}_{2} \mathrm{O}_{2}$ in ambient air by wet annular denuder system, Atmos. Environ., 22, 2541-2548, 1988.

Khlystov, A., Wyers, G. P., and Slanina, J.: The steam-jet aerosol collector, Atmos. Environ., 29, 2229-2234, 1995.

Krupa, S. V.: Sampling and physico-chemical analysis of precipitation: a review, Environ. Pollut., 120, 565-594, 2002.

Li, H. Y., Han, Z. W., Cheng, T. T., Du, H. H., Kong, L. D., Chen, J. M., Zhang, R. J., and Wang, W. J.: Agricultural fire impacts on the air quality of Shanghai during summer harvesttime, Aerosol Air Qual. Res., 10, 95-101, doi:10.4209/aaqr.2009.08.0049, 2010.

Makkonen, U., Virkkula, A., Mäntykenttä, J., Hakola, H., Keronen, P., Vakkari, V., and Aalto, P. P.: Semi-continuous gas and inorganic aerosol measurements at a Finnish urban site: comparisons with filters, nitrogen in aerosol and gas phases, and aerosol 
acidity, Atmos. Chem. Phys., 12, 5617-5631, doi:10.5194/acp12-5617-2012, 2012.

Massad, R.-S., Nemitz, E., and Sutton, M. A. Review and parameterisation of bi-directional ammonia exchange between vegetation and the atmosphere, Atmos. Chem. Phys., 10, 10359-10386, doi:10.5194/acp-10-10359-2010, 2010.

McCulloch, R. B, Few, G. S., Murray Jr., G. C., and Aneja, V. P.: Analysis of ammonia, ammonium aerosols and acid gases in the atmosphere at a commercial hog farm in eastern North Carolina, USA, Environ. Pollut., 102, 263-268, 1998.

Neuman, J. A., Huey, L. G., Ryerson, T. B., and Fahey, D. W.: Study of inlet materials for sampling atmospheric nitric acid, Environ. Sci. Technol., 33, 1133-1136, 1999.

Nie, W., Wang, T., Gao, X., Pathak, R. K., Wang, X., Gao, R., Zhang, Q., Yang, L., and Wang, W. X.: Comparison among filterbased, impactor-based and continuous techniques for measuring atmospheric fine sulfate and nitrate, Atmos. Environ., 44, 43964403, doi:10.1016/j.atmosenv.2010.07.047, 2010.

Phillips, G. J., Makkonen, U., Schuster, G., Sobanski, N., Hakola, $\mathrm{H}$., and Crowley, J. N: The detection of nocturnal $\mathrm{N}_{2} \mathrm{O}_{5}$ as $\mathrm{HNO}_{3}$ by alkali- and aqueous-denuder techniques, Atmos. Meas. Tech., 6, 231-237, doi:10.5194/amt-6-231-2009, 2013.

Ramundo, R. A. and Seastedt, T. R.: Site-specific underestimation of wetfall $\mathrm{NH}_{4}^{+}$using NADP data, Atmos. Environ., 24A, 30933095, 1990.

Schaap, M., Otjes, R. P., and Weijers, E. P.: Illustrating the benefit of using hourly monitoring data on secondary inorganic aerosol and its precursors for model evaluation, Atmos. Chem. Phys., 11, 11041-11053, doi:10.5194/acp-11-11041-2011, 2011.

Sickles II, J. E., Hodson, L. L., and Vorburger, L. M.: Evaluation of the filter pack for long duration sampling of ambient air, Atmos. Environ., 33, 2187-2202, 1999.

Slanina, J., ten Brink, H. M., Otjes, R. P., Even, A., Jongejan, P., Khlystov, A., Waijers-Ijpelaan, A., and Hu, M.: The continuous analysis of nitrate and ammonium in aerosols by the steam jet aerosol collector (SJAC): extension and validation of the methodology, Atmos. Environ., 35, 2319-2330, 2001.

ten Brink, H., Otjes, R., Jongejan, P., and Slanina, J.: An instrument for semi-continuous monitoring of the size-distribution of nitrate, ammonium, sulphate and chloride in aerosol, Atmos. Environ., 41, 2768-2779, 2007.

Thomas, R. M., Trebs, I., Otjes, R., Jongejan, P. A. C., ten Brink, H., Phillips, G., Kortner, M., Meixner, F. X., and Nemitz, E.: An automated analyzer to measure surface-atmosphere exchange fluxes of water soluble inorganic aerosol compounds and reactive trace gases, Environ. Sci. Technol., 43, 1412-1418, 2009.
Trebs, I., Meixner, F. X., Slanina, J., Otjes, R., Jongejan, P., and Andreae, M. O.: Real-time measurements of ammonia, acidic trace gases and water-soluble inorganic aerosol species at a rural site in the Amazon Basin, Atmos. Chem. Phys., 4, 967-987, doi:10.5194/acp-4-967-2004, 2004.

US Environmental Protection Agency (US EPA): Method 350.1: Determination of ammonia nitrogen by semi-automated colorimetry, Environmental Monitoring Systems Laboratory, Office of Research and Development, Cincinnati, OH, 1993a.

US Environmental Protection Agency (US EPA): Method 300.0: Determination of inorganic anions by chromatography, Environmental Monitoring Systems Laboratory, Office of Research and Development, Cincinnati, OH, 1993 b.

US Environmental Protection Agency (US EPA): Compendium method IO-4.2: Determination of reactive acidic and basic gases and strong acidity of atmospheric particles $(<2.5 \mu \mathrm{m})$, Center for Environmental Research Information, Office of Research and Development, Cincinnati, OH, 1999.

US Environmental Protection Agency (US EPA): Environmental Technology Verification report: Applikon MARGA semicontinuous ambient air monitoring system, US EPA, Office of Research and Development, EPA/600/R11/106VR; available at: http://nepis.epa.gov/Adobe/PDF/P100CH7N.pdf, 2011.

Walker, J. T., Robarge, W. P., Shendrikar, A., and Kimball, H.: Inorganic $\mathrm{PM}_{2.5}$ at a U.S. agricultural site, Environ. Pollut., 139, 258-271, 2006.

Weber, R. J., Orsini, D., Daun, Y., Lee, Y.-N., Klotz, P. J., and Brechtel, F.: A particle into-liquid collector for rapid measurement of aerosol bulk chemical composition, Aerosol Sci. Technol., 35, 718-727, doi:10.1080/02786820152546761, 2001.

Wolff, V., Trebs, I., Ammann, C., and Meixner, F. X.: Aerodynamic gradient measurements of the $\mathrm{NH}_{3}-\mathrm{HNO}_{3}-\mathrm{NH}_{4} \mathrm{NO}_{3}$ triad using a wet chemical instrument: an analysis of precision requirements and flux errors, Atmos. Meas. Tech., 3, 187-208, doi:10.5194/amt-10-187-2010, 2010.

Wyers, G. P., Otjes, R. P., and Slanina, J.: A continuous-flow denuder for the measurement of ambient concentrations and surface-exchange fluxes of ammonia, Atmos. Environ., 27, 2085-2090, 1993 